Wang, Qingqing; Zhang, Qi; Ma, Zhiqiang; Ge, Baozhu; Xie, Conghui; Zhou, Wei; Zhao, Jian; Xu, Weiqi; Du, Wei; Fu, Pingqing; Lee, James; Nemitz, Eiko; Cowan, Nicholas; Mullinger, Neil; Cheng, Xueling; Zhou, Libo; Yue, Siyao; Wang, Zifa; Sun, Yele. 2019. Temporal characteristics and vertical distribution of atmospheric ammonia and ammonium in winter in Beijing.

(C) 2019 Elsevier B.V.

This manuscript version is made available under the CC-BY-NC-ND 4.0 license http://creativecommons.org/licenses/by-nc-nd/4.0/ (cc) EY-NC-ND

This version available http://nora.nerc.ac.uk/523600/

NERC has developed NORA to enable users to access research outputs wholly or partially funded by NERC. Copyright and other rights for material on this site are retained by the rights owners. Users should read the terms and conditions of use of this material at http://nora.nerc.ac.uk/policies.html\#access

NOTICE: this is an unedited manuscript accepted for publication. The manuscript will undergo copyediting, typesetting, and review of the resulting proof before publication in its final form. During the production process errors may be discovered which could affect the content. A definitive version was subsequently published in Science of the Total Environment (2019), 681. 226234. https://doi.org/10.1016/i.scitotenv.2019.05.137

www.elsevier.com/ 


\section{Temporal characteristics and vertical distribution of atmospheric ammonia and ammonium in winter in Beijing}

Qingqing Wang ${ }^{\mathrm{a}, \mathrm{b}, \mathrm{c}}$, Qi Zhang ${ }^{\mathrm{b} *}$, Zhiqiang Ma ${ }^{\mathrm{d}}$, Baozhu Ge ${ }^{\mathrm{a}}$, Conghui Xie ${ }^{\mathrm{a}, \mathrm{c}}$, Wei Zhou ${ }^{\mathrm{a}, \mathrm{c}}$, Jian Zhao ${ }^{\mathrm{a}, \mathrm{c}}$, Weiqi $\mathrm{Xu}^{\mathrm{a}, \mathrm{c}}$, Wei Du ${ }^{\mathrm{a}}$, Pingqing Fu ${ }^{\mathrm{e}}$, James Lee ${ }^{\mathrm{f}}$, Eiko Nemitz ${ }^{\mathrm{g}}$, Nicholas Cowan ${ }^{\mathrm{g}}$, Neil Mullinger ${ }^{\mathrm{g}}$, Xueling Cheng ${ }^{\mathrm{a}}$, Libo Zhou ${ }^{\mathrm{a}}$, Siyao Yue ${ }^{\mathrm{a}, \mathrm{c}}$, Zifa Wang ${ }^{\mathrm{a}}$, Yele Sun ${ }^{\mathrm{a}, \mathrm{c}^{*}}$

${ }^{a}$ State Key Laboratory of Atmospheric Boundary Layer Physics and Atmospheric Chemistry, Institute of Atmospheric Physics, Chinese Academy of Sciences, Beijing 100029, China

${ }^{\mathrm{b}}$ Department of Environmental Toxicology, University of California, Davis, CA 95616, USA

${ }^{c}$ University of Chinese Academy of Sciences, Beijing 100049, China

${ }^{\mathrm{d}}$ Institute of Urban Meteorology, China Meteorological Administration, Beijing 100089, China

${ }^{\mathrm{e}}$ Institute of Surface-Earth System Science, Tianjin University, Tianjin 300072, China

${ }^{\mathrm{f}}$ National Centre for Atmospheric Science, University of York, York, UK

${ }^{\mathrm{g}}$ Centre for Ecology \& Hydrology, Bush Estate, Penicuik, Midlothian, EH26 0QB, UK

Correspondence: Qi Zhang (dkwzhang@ucdavis.edu); Yele Sun (sunyele@mail.iap.ac.cn) 


\section{ABSTRACT}

To understand the temporal characteristics and vertical distributions of ammonia $\left(\mathrm{NH}_{3}\right)$ and ammonium $\left(\mathrm{NH}_{4}\right)$ in urban Beijing, we conducted ground-based and tower-based measurements of gaseous $\mathrm{NH}_{3}$ and submicron aerosol composition. The average mixing ratio of $\mathrm{NH}_{3}$ was $16.5 \pm 7.4$ ppb, ranging from 3.8 to $36.9 \mathrm{ppb}$. Gas-to-particle partitioning of $\mathrm{NH}_{\mathrm{x}}\left(=\mathrm{NH}_{3}+\mathrm{NH}_{4}\right)$ played a significant role on $\mathrm{NH}_{3}$ concentration as the molar ratio of $\mathrm{NH}_{3}$ to $\mathrm{NH}_{\mathrm{x}}$ decreased as a function of $\mathrm{NH}_{4}$ concentration. The $\mathrm{NH}_{3}$ concentrations increased as a function of $\mathrm{PM}_{1}$ at lower levels $(<125 \mu \mathrm{g}$ $\mathrm{m}^{-3}$ ), but remained relatively constant at higher $\mathrm{PM}$ and $\mathrm{NH}_{4}$ levels, indicating an enhanced gas-to-particle conversion of $\mathrm{NH}_{3}$ during highly polluted conditions. The potential sources of $\mathrm{NH}_{\mathrm{x}}$ were found to include fossil fuel combustion and biomass burning. Regional transport could also play an important role on $\mathrm{NH}_{3}$ concentration during the formation stage of haze episodes due to particle-to-gas conversion. Four distinctive types of vertical profiles ( $87 \%$ of the time) of both $\mathrm{NH}_{3}$ and fine particle light extinction coefficient $\left(b_{\text {ext }}\right)$ were observed and they were associated with well-mixed atmosphere, fast accumulation of local emissions, regional transport aloft, and the formation of low urban boundary layer, respectively. However, the vertical profiles of $\mathrm{NH}_{3}$ typically (96\% of the time) showed a more homogeneous characteristic than those of $b_{\text {ext }}$ below $260 \mathrm{~m}$, except periods with both strong temperature inversion and large aerosol gradient, the formation of urban boundary layer shall cause a significant transition in the vertical distribution of $\mathrm{NH}_{3}$ below $260 \mathrm{~m}$. During highly polluted situations $\left(\mathrm{PM}_{1}>125 \mu \mathrm{g} \mathrm{m}^{-3}\right)$, the strong effect of gas-to-particle partitioning of $\mathrm{NH}_{\mathrm{x}}$ sometimes (7\% of the time) caused opposite trends in vertical profiles of $\mathrm{NH}_{3}$ and $b_{\text {ext }}$.

\section{Key words:}

Ammonia, $\mathrm{NH}_{\mathrm{x}}$, Vertical distribution, Extinction coefficient, Beijing 


\section{Introduction}

$\mathrm{NH}_{3}$ plays an important role in urban air pollution processes, such as the formation of secondary inorganic aerosol species of SNA (sulfate + nitrate + ammonium) (Wang et al., 2011). Other fine particle chemical species, e.g., organics, chloride, nitrate, sulfate and black carbon are relatively well understood during severe haze episodes in China (Sun et al., 2013; Wang et al., 2015; Zhang et al., 2015), the evolution mechanisms for ammonium remain poorly characterized. In addition, $\mathrm{NH}_{\mathrm{x}}(=$ $\mathrm{NH}_{3}+\mathrm{NH}_{4}$ ) control has been found playing an effective role on reduction of $\mathrm{PM}_{2.5}$ pollution (Giannadaki et al., 2018; Guo et al., 2018; Pozzer et al., 2017). $\mathrm{NH}_{3}$ is mainly released from agricultural activities and breeding industry on a global scale (Van Damme et al., 2018), however, the sources for the high level of $\mathrm{NH}_{3}$ observed in urban areas remain a controversial topic (Zhang et al., 2017) as there are little local contributions from the two sources mentioned above. Traffic emission has been reported as an important source for $\mathrm{NH}_{3}$ in urban areas (Elser et al., 2018). Coal combustion and biomass burning, which are major contributors to severe haze pollution in Beijing, have been found to emit significant amount of $\mathrm{NH}_{3}$ (Li et al., 2016). Some point sources, e.g., wastewater treatment plants, can also emit $\mathrm{NH}_{3}$ (Van Damme et al., 2018). The sources for $\mathrm{NH}_{3}$ were studied via $\mathrm{N}$ isotopic ratios in nitrate and simulated $\mathrm{NH}_{3}$ in Pan et al. $(2016 ; 2018)$, and via direct measurement of $\mathrm{NH}_{3}$ in Chang et al. (2015), however, the relationship between ammonium and $\mathrm{NH}_{3}$ was not further discussed. $\mathrm{NH}_{3}$ concentration was usually found depending exponentially on temperature (Chang et al., 2015), especially during winter time (Teng et al., 2017), indicating a significant effect of gas-particle partitioning on the concentration of $\mathrm{NH}_{3}$. The uncertainties of ammonia emissions, together with the huge variations in the relationship between emissions and ambient concentrations of $\mathrm{NH}_{3}$, are causing difficulties in abating $\mathrm{NH}_{4}$ levels. Thus, it is worthwhile to study the sources and 
evolution mechanisms for $\mathrm{NH}_{\mathrm{x}}$ via simultaneous measurement of both gaseous $\mathrm{NH}_{3}$ and particulate ammonium, especially in severely polluted megacities that suffer high level of $\mathrm{NH}_{\mathrm{x}}$ (Wang et al., 2015).

The complex vertical evolution of air pollutants is attracting attention due to its strong influence on the accurate prediction of air quality models (Wang et al., 2014). Regional transport usually affected air pollution in urban areas initially above the urban canopy, which could be observed based on the vertical distribution of air pollutants (Sun et al., 2015; Wang et al., 2018). The weekly vertical distribution of ammonia $\left(\mathrm{NH}_{3}\right)$ measured at 16 different heights on the Beijing $325 \mathrm{~m}$ meteorological tower (BMT) showed that $\mathrm{NH}_{3}$ was rich during all seasons below $320 \mathrm{~m}$ (Zhang et al., 2018). High time resolution method for vertically resolved studies shows that $\mathrm{NH}_{3}$ concentration at higher altitudes appears to be driven by transport while that at lower altitudes is strongly influenced by surface emissions and boundary layer height (Tevlin et al., 2017). To date, the vertical profiles of $\mathrm{NH}_{\mathrm{x}}$ at urban area in highly polluted megacities in China have rarely been studied.

In this study, highly time-resolved measurements of gaseous $\mathrm{NH}_{3}$ were conducted at ground site, and the vertically resolved measurements of $\mathrm{NH}_{3}$ and fine particle extinction coefficient $\left(b_{\text {ext }}\right)$ were performed from ground level to $260 \mathrm{~m}$ on the BMT in November and December 2016. In addition, simultaneous real-time measurements of ammonium in $\mathrm{PM}_{1}$ particles were conducted at the ground level and $260 \mathrm{~m}$ from the tower, along with measurements of the other $\mathrm{PM}_{1}$ species (i.e., organics, sulfate, nitrate, chloride, and $\mathrm{BC}$ ) and trace gases (i.e., $\mathrm{CO}, \mathrm{SO}_{2}, \mathrm{O}_{3}$ and nitrogen oxides). Our goals are to elucidate the vertical evolution mechanisms of $\mathrm{NH}_{\mathrm{x}}$ and the potential sources for $\mathrm{NH}_{3}$ within urban boundary layer (UBL) during wintertime in Beijing. 


\section{Experimental methods}

\subsection{Sampling site}

All measurements were conducted at an urban site between the $3^{\text {rd }}$ and $4^{\text {th }}$ ring road in Beijing located at the Tower Branch of Institute of Atmospheric Physics (TBIAP, $39^{\circ} 58^{\prime} \mathrm{N}, 116^{\circ} 22^{\prime} \mathrm{E}$; elevation: 49 m ASL), Chinese Academy of Sciences from November 16 to December 10, 2016. The site is surrounded by roads, expressways, gas stations, residential areas, park, commercial buildings, and restaurants (Fig. 1).

\subsection{Ground measurements}

$\mathrm{NH}_{3}$ at ground level was measured using an online LGR ammonia analyzer (DTL-100, Los Gatos Research, California) (Baer et al., 2002) at a time resolution of about 50 s (Location B; Fig. 1). Meng et al. (2018) reported that there was a lag in the results of the LGR ammonia analyzer, and hourly average could reduce this influence. $\mathrm{NH}_{3}$ measured by the LGR ammonia analyzer tracked well with the measurement at $102 \mathrm{~m}$ on the BMT from an open path quantum cascade-laser (QCL)-based $\mathrm{NH}_{3}$ sensor (Aerodyne Research Inc., USA) using a $3 \mathrm{~m}$ fast-response counter-flow impactor inlet, with $R^{2}=0.70$, slope $=0.89$ (Fig. S1). Note that a slight time lag of a few seconds was observed between the two measurements. However, the water vapor measured at $50 \mathrm{~s}$ resolution by the LGR ammonia analyzer compared extremely well with that measured at $2 \mathrm{~s}$ resolution from a ground meteorological station $\left(R^{2}=0.99\right.$, slope $=1.19$; Fig. $\left.\mathrm{S} 1\right)$, and the water vapor and $\mathrm{NH}_{3}$ measured by the LGR ammonia analyzer were also highly consistent, indicating that the time lag between the LGR ammonia analyzer and the QCL-based $\mathrm{NH}_{3}$ sensor can be ignored.

Gas analyzers (Thermo Scientific) were deployed from a nearby container (Location C; Fig. 1) 
to measure $\mathrm{NO} / \mathrm{NO}_{\mathrm{y}}\left(\right.$ Model 42i), $\mathrm{CO}$ (Model 48i), $\mathrm{O}_{3}$ (Model 49i), and $\mathrm{SO}_{2}($ Model 43i)

simultaneously. $\mathrm{CO}_{2}$ at $8 \mathrm{~m}$ above the ground were measured from the tower using a LI-7500 $\mathrm{CO}_{2} / \mathrm{H}_{2} \mathrm{O}$ infrared gas analyzers (LI-COR, Inc., Nebraska, USA) on the BMT (Liu et al., 2015).

At the rooftop of a two-story building ( 8 m high) (Location A; Fig. 1), non-refractory submicron aerosol $\left(\mathrm{NR}-\mathrm{PM}_{1}\right)$ species, including organics $(\mathrm{Org})$, sulfate $\left(\mathrm{SO}_{4}\right)$, nitrate $\left(\mathrm{NO}_{3}\right)$, ammonium $\left(\mathrm{NH}_{4}\right)$ and chloride $(\mathrm{Chl})$ were measured by an Aerodyne High-Resolution Time-of-Flight Aerosol Mass Spectrometer (AMS hereafter); BC was measured by a 7-wavelength aethalometer (AE33, Magee Scientific Corp.); extinction coefficients of dry fine $\mathrm{PM}_{1}$ at $630 \mathrm{~nm}$ by a

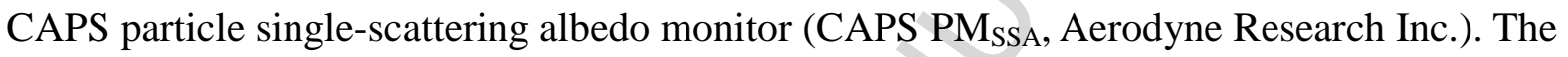
organic aerosol spectral matrices of the AMS were analyzed by Positive Matrix Factorization (PMF) to resolve 6 organic aerosol (OA) factors (Xu et al., 2018), i. e., a fossil-fuel-related OA (FFOA), a cooking OA (COA), a biomass burning OA (BBOA), an oxidized POA (OPOA), an oxygenated OA (OOA), and an aqueous-phase OOA (aq-OOA). Measurements of $\mathrm{NH}_{3}$ and $\mathrm{PM}_{1}$ chemical species at ground level were extended to December 222016.

\subsection{Measurements at $260 \mathrm{~m}$ above the ground}

Simultaneous measurements of $\mathrm{BC}, \mathrm{CO}, \mathrm{O}_{3}$, and $\mathrm{SO}_{2}$ were conducted at $260 \mathrm{~m}$ on the tower using the same type of instruments as those used for the ground observations except that NR-PM was measured with an Aerodyne Aerosol Chemical Speciation Monitor (ACSM) (Sun et al., 2015). The ACSM had been deployed in parallel with the AMS through the same sampling inlet during December 14 to 16,2016 , and the $R^{2}$ for the NR-PM 1 species comparisons between the two instruments were $0.97,0.98,0.99,0.99$, and 0.98, respectively for $\mathrm{Org}, \mathrm{SO}_{4}, \mathrm{NO}_{3}, \mathrm{NH}_{4}$, and Chl. 
High correlation for parallel sampling comparisons of BC and precursor gases with the same model of instruments for measurement at the two heights were also confirmed. $b_{\text {ext }}(\lambda=630 \mathrm{~nm})$ of $\mathrm{PM}_{2.5}$ at

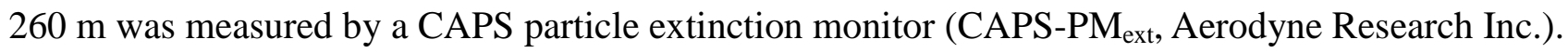

\subsection{Vertically resolved measurements}

A container suspended from a cable car style lift system installed on the BMT was used for vertically resolved measurements at a constant moving speed of $\sim 8 \mathrm{~m} \mathrm{~min}^{-1}$. The ammonia analyzer and a Photo-Acoustic Extinctiometer (PAX, Droplet Measurement Technologies, Inc.) were placed inside the container for measurements of $\mathrm{NH}_{3}$ and light extinction coefficient at $\lambda=870 \mathrm{~nm}$ of $\mathrm{PM}_{2.5}$, respectively. All instruments were powered by Uninterrupted Power Supply, and the vertically resolved measurements were performed between the ground level and aloft about every $4 \mathrm{~h}$ during daytime $(260 \mathrm{~m})$ and every $6 \mathrm{~h}$ during nighttime $(240 \mathrm{~m})$ for safety; for the remainder of the time the instruments provided ground measurements, which was similar to the arrangements reported in Wang et al. (2018). In total, 50 sets of vertical profiles (VPs) for $b_{\text {ext }}\left(\mathrm{VPs} \_b_{\text {ext }}\right)$ and $\mathrm{NH}_{3}\left(\mathrm{VPs} \_\mathrm{NH}_{3}\right)$ were obtained. Due to the interruption of power supply, 4 VPs_NH $\mathrm{NH}_{3}$ were incomplete. Wind speed (WS), wind direction (WD), relative humidity $(\mathrm{RH})$, and temperature $(T)$ at 15 different heights $(8,15,32$, $47,63,80,100,120,140,160,180,200,240,280$, and $320 \mathrm{~m}$ ) were measured on the BMT.

\section{Results and discussion}

\subsection{Overview of pollution levels}

The average mass concentration of $\mathrm{PM}_{1}$ was $83.3 \pm 80.3 \mu \mathrm{g} \mathrm{m}^{-3}$ (Table S1) from November 16 to December 10, with organics, nitrate, sulfate, ammonium, chloride, and black carbon accounted for on average $39.8 \%, 19.6 \%, 16.3 \%, 10.0 \%, 7.3 \%$, and $7.0 \%$, respectively, indicating a high level of 
aerosol pollution in urban Beijing. The average $\mathrm{NH}_{3}$ mixing ratio during this study was $16.5 \pm 7.4$ ppb $\left(12.3 \pm 5.5 \mu \mathrm{g} \mathrm{m}^{-3}\right)$, higher than the values previously observed in Shanghai (about $5 \mathrm{ppb}$ in winter and autumn) (Chang et al., 2015) and in winter 2007 in Beijing $\left(5.5 \mu \mathrm{g} \mathrm{m}^{-3}\right)$, lower than the level observed at a rural site (36.2 ppb) and in urban Beijing in summer $2007\left(25.4 \mu \mathrm{g} \mathrm{m}^{-3}\right.$ ) (Shen et al., 2011), and was less than 1/10 of those observed in tunnel studies (Chang et al., 2015; Liu et al., 2014). Compared with the results in the heating season of 2012 (Wang et al., 2015), $\mathrm{SO}_{2}$ was lower by more than $50 \%$. However, $\mathrm{CO}, \mathrm{NO}, \mathrm{NO}_{2}$ were at comparable levels, suggesting similar intensity of traffic emission but a significant reduction of coal combustion emission. High values of $\mathrm{O}_{3}$ could be observed both at daytime and nighttime with low $\mathrm{PM}_{1}$ mass loadings, indicating that the high background of $\mathrm{NO}_{\mathrm{x}}$ and VOCs in Beijing (Fig. 2). High level of $\mathrm{O}_{3}$ and low levels of other pollutants typically appeared when the northwest wind prevailed (Fig. 2). Low values of $\mathrm{O}_{3}$ during high pollution episodes were relevant to the lower solar radiation and weak oxidation of atmospheric condition, and high $\mathrm{NO}$ that titrated $\mathrm{O}_{3}$ substantially as the diurnal cycle of $\mathrm{O}_{3}$ was generally in accordance with that of solar radiation (Wang et al., 2015), and was opposite to those of $\mathrm{NO}_{\mathrm{x}}, \mathrm{NO}_{2}$, and $\mathrm{SO}_{4}$ (Fig. S2). High $\mathrm{RH}$ generally coincided with highly polluted episodes, which is a common feature for severe haze in Beijing (Sun et al., 2014b; Sun et al., 2012; Sun et al., 2013). High $\mathrm{f}_{\mathrm{NH} 3}(=$ $\mathrm{NH}_{3} / \mathrm{NH}_{\mathrm{x}}$ in molar concentrations) appeared during low pollution situations (Fig. 2f) partly due to low $\mathrm{RH}$ which tended to inhibit the transformation of $\mathrm{NH}_{3}$ to ammonium.

The diurnal cycle of $\mathrm{NH}_{\mathrm{x}}$ was similar to those of $\mathrm{Chl}, \mathrm{BC}, \mathrm{CO}$, and $\mathrm{NO}$, suggesting coal combustion and traffic were two important sources for $\mathrm{NH}_{3}$ and $\mathrm{NH}_{4}$. Both $\mathrm{NO}$ and $\mathrm{CO}_{2}$ peaked at 8:00, indicating that traffic emission was an important source of $\mathrm{CO}_{2}$ in our study. The diurnal profile of $\mathrm{SO}_{2}$, a gas species dominantly from coal combustion emissions, generally agreed well with that of 
$\mathrm{NH}_{3}\left(R^{2}=0.67\right)$, with low values occurring around 8:00 and 15:00 - 18:00, and high values at nighttime. Previous studies also showed that fossil fuel emissions could contribute $90 \%$ of the total $\mathrm{NH}_{3}$ during haze days in urban Beijing (Pan et al., 2016). These results suggest that coal combustion could be an important source of $\mathrm{NH}_{3}$ in urban Beijing. The similar diurnal trends of $\mathrm{NH}_{3}$ and $\mathrm{NH}_{4}$ indicated a regional transport characteristic for $\mathrm{NH}_{\mathrm{x}}$ during this study. A great difference between the diurnal cycles of $\mathrm{NH}_{3}$ and $\mathrm{NH}_{\mathrm{x}}$ occurred during 8:00 - 16:00 when there was a negative correlation between $\mathrm{f}_{\mathrm{NH} 3}$ and $\mathrm{NH}_{\mathrm{x}}$ due to the conversion of particle to gas.

\subsection{Gas-particle partitioning of $\mathrm{NH}_{\mathrm{x}}$}

In Fig. 3, during clean periods $\left(\mathrm{PM}_{1} \leq 17 \mu \mathrm{g} \mathrm{m}^{-3}\right) \mathrm{NH}_{3}$ was about $8 \mu \mathrm{g} \mathrm{m} \mathrm{m}^{-3}(10 \mathrm{ppb}) . \mathrm{f}_{\mathrm{NH} 3}$ correlated negatively with $\mathrm{PM}_{1}$, indicating enhanced gas-to-particle conversion of $\mathrm{NH}_{3}$ during high PM pollution situation (Figs. 3 and S3). Line A, Zones B, C and D were marked by dotted lines in Fig. 3. Line A illustrates the average background $\mathrm{NH}_{3}$ concentration that appeared during clean days with strong northeast wind (Fig. 2), when $\mathrm{NH}_{3}$ in Beijing during the winter season was mainly affected by emissions from regional agriculture and breeding industry of north China. $\mathrm{NH}_{3}$ increased fast with the increase of $\mathrm{PM}_{1}$ in Zone $\mathrm{B}\left(17<\mathrm{PM}_{1} \leq 125 \mu \mathrm{g} \mathrm{m}^{-3}\right)$, indicating the linear and positive correlation with the accumulation of $\mathrm{PM}_{1}$. Average $\mathrm{NH}_{3}$ was relatively constant at an average $( \pm 1 \sigma)$ concentration of $17.0 \pm 3.5 \mu \mathrm{g} \mathrm{m}^{-3}$ (or $22.8 \pm 4.7 \mathrm{ppb}$ ) in Zone $\mathrm{C}\left(125<\mathrm{PM}_{1} \leq 272 \mu \mathrm{g} \mathrm{m}^{-3}\right.$ ), and especially in zone $\mathrm{D}\left(272<\mathrm{PM}_{1} \leq 500 \mu \mathrm{g} \mathrm{m}^{-3}\right)$. This is an indication that the basic $\mathrm{NH}_{3}$ gas was still in excess relative to acidic gases (e.g., $\mathrm{HNO}_{3}$ and $\mathrm{HCl}$ ) during severe haze episodes.

There was a good exponential relationship between $\mathrm{f}_{\mathrm{NH} 3}$ and $\mathrm{NH}_{4}$ (Fig. 4), as the $R^{2}$ and Slope between the measured and the reconstructed values of $\mathrm{f}_{\mathrm{NH} 3}$ were 0.92 and 0.99 , respectively (Fig. S4). 
Exponential relationships were usually observed between $T$ and concentration of $\mathrm{NH}_{3}$ (Aneja et al., 2000; Chang et al., 2015; Teng et al., 2017) as $T$ is an important factor for gas-particle partitioning. The correlation between $\mathrm{NH}_{3}$ and dew point (DP) was tightest among those of $\mathrm{NH}_{3}, \mathrm{NH}_{\mathrm{x}}$, or $\mathrm{NH}_{4}$ vs DP, RH, or $T$ (Table S2). There was a border line of $T$ at about $5{ }^{\circ} \mathrm{C}$, as high values of $\mathrm{NH}_{4}$ and $\mathrm{NH}_{3}$ appeared when $T<5{ }^{\circ} \mathrm{C}$ and $T>5^{\circ} \mathrm{C}$, respectively (Fig. 5).

3.3. Potential sources and emission ratio (ER) for $\mathrm{NH}_{\mathrm{x}}$.

Considering the strong activity of gas-particle partitioning of $\mathrm{NH}_{3}$, it is reasonable to detect the potential sources for $\mathrm{NH}_{\mathrm{x}}$ instead of for $\mathrm{NH}_{3}$ as $\mathrm{NH}_{\mathrm{x}}$ approximately had a linear relationship with $\mathrm{PM}_{1}$. The $R^{2}$ between the time series of tracers of potential sources and $\mathrm{NH}_{3}$ and $\mathrm{NH}_{\mathrm{x}}$ are presented in Table S3 for different time resolution ( $5 \mathrm{~min}, 6 \mathrm{~h}$, and 1 day), in view of some instantaneous processes that might cause a delay in increase of $\mathrm{NH}_{3}$, e.g., due to conversion to $\mathrm{NH}_{4}$ through secondary aerosol formation. Tracers that had weak correlations with $\mathrm{NH}_{3}$ and $\mathrm{NH}_{\mathrm{x}}$ suggested insignificant contributions from the corresponding source, e. g., cooking was not an identified source of $\mathrm{NH}_{\mathrm{x}}$. In addition, $\mathrm{NH}_{3}$ from traffic emission can vary not only between different running status of a car (Sun et al., 2014a), but also between different cars (Li et al., 2006). Hence, here we split the time series of $\mathrm{NH}_{\mathrm{x}}$ into 35 segments to calculate the $R^{2}$ and slopes between the tracers and $\mathrm{NH}_{\mathrm{x}}$ (Fig. S5).

$\mathrm{CO}, \mathrm{BC}$, and Chl correlated well with $\mathrm{NH}_{\mathrm{x}}$, with $R^{2}=0.77,0.72$ and 0.68 , respectively, suggesting that traffic and coal combustion were two significant sources of $\mathrm{NH}_{\mathrm{x}}$ (Wang et al., 2015). Zhang et al. (2018) reported that local sources such as traffic emissions appeared to be important contributors to $\mathrm{NH}_{3}$ in urban Beijing. $\mathrm{CO}_{2}$ had relatively lower correlation with $\mathrm{NH}_{\mathrm{x}}$ than $\mathrm{CO}$ did at 
measurement time resolution of $5 \mathrm{~min}$. Incomplete combustion of fossil fuels, e.g., cold start or low running speed of the car (Sun et al., 2014a), and charcoal barbecue or scattered coal burning (Li et al.,

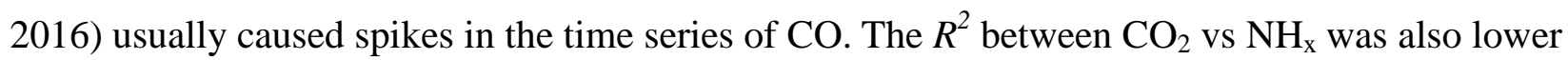
than $\mathrm{CO}$ vs $\mathrm{NH}_{\mathrm{x}}$ for lower time resolution of 6 hours or 1 day, indicating that incomplete combustion of fossil fuels was an important contributor to $\mathrm{ER}$ of $\mathrm{NH}_{\mathrm{x}}$. In view of the highly polluted surrounding areas (Wang et al., 2014), regional transport of $\mathrm{NH}_{4}$ was likely a strong contributor to $\mathrm{NH}_{\mathrm{x}}$ in Beijing. As the $\mathrm{N}$ fertilizer used in November and December were as low as $\sim 2 \%$ of the whole year (Fu et al., 2015), and the $\mathrm{NH}_{3}$ levels were correspondingly low in the two months (Damme et al., 2015) in the North China Plain, thus the agricultural emission from regional transport was unlikely an important source of $\mathrm{NH}_{3}$ in Beijing during our study period.

$\mathrm{NH}_{\mathrm{x}}$ correlated better with Aq-OOA $(\mathrm{O}: \mathrm{C}=0.82)$ and semi-volatile species such as particulate nitrate $\left(R^{2}=0.83\right.$, and 0.88 , respectively) than with the more oxidized OOA $(\mathrm{O}: \mathrm{C}=1.09)$ and $\mathrm{SO}_{4}$ $\left(R^{2}=0.58\right.$ and 0.81 , respectively), appearing that local sources contributed more significantly to $\mathrm{NH}_{\mathrm{x}}$ in urban Beijing. High correlation coefficients between $\mathrm{O}_{3}$ and $\mathrm{NH}_{\mathrm{x}}$ in our study were all observed during noon time (Fig. S5), e.g., in segments 6, 16, 20, 26, 32, 33, 35, when $\mathrm{NH}_{\mathrm{x}}$ were also correlated well with BBOA, or FFOA. $\mathrm{O}_{3}$ could be produced both from photochemical process and nighttime chemistry (Millet et al., 2016), and $\mathrm{NH}_{3}$ was found to promote the generation of secondary organic aerosol (Huang et al., 2012; Na et al., 2006) during ozone-initiated reaction. Further research on the behavior of $\mathrm{NH}_{\mathrm{x}}$ during atmospheric chemical reactions is still needed.

$\mathrm{NH}_{\mathrm{x}}$ correlated best with $\mathrm{CO}$ among all primary tracers, thus $\mathrm{CO}$ was the most typical primary species for ER calculation of $\mathrm{NH}_{\mathrm{x}}$ here. The high correlations of $\mathrm{CO}$ and $\mathrm{NO}_{\mathrm{x}}\left(R^{2}=0.74\right)$ and vs $\mathrm{Chl}$ 
$\left(R^{2}=0.84\right)$ suggest that traffic and coal combustion were the major sources of $\mathrm{CO}$ in our study. The ER of $\left[\mathrm{NH}_{\mathrm{x}}\right] /[\mathrm{CO}]$ (ppbv/ppbv) ranged between $0.001-0.03$ with a mean value of 0.011 (Table S4). The mean value was significantly lower than the ER of $\left[\mathrm{NH}_{3}\right] /[\mathrm{CO}](\mathrm{ppbv} / \mathrm{ppbv}$ ) reported previously for traffic emissions $(\sim 0.03)$ (Sun et al., 2014a), and the automobiles and dairy facilities emission $(\sim$ 0.035) (Nowak et al., 2012). Biomass burning emissions and secondary formation also likely played a significant role for the high level of $\mathrm{NH}_{\mathrm{x}}$ in Beijing as the $\mathrm{ER}$ of $\left[\mathrm{NH}_{\mathrm{x}}\right] /[\mathrm{BBOA}]\left(1.99 \mathrm{ppbv} / \mu \mathrm{g} \mathrm{m}^{-3}\right)$ was higher than that of $\left[\mathrm{NH}_{\mathrm{x}}\right] /[\mathrm{FFOA}]\left(1.39 \mathrm{ppbv} / \mu \mathrm{g} \mathrm{m}{ }^{-3}\right)$, and the ER of $\left[\mathrm{NH}_{\mathrm{x}}\right] /[\mathrm{OOA}+\mathrm{aq}-\mathrm{OOA}]$ (3.86 $\left.\mathrm{ppbv} / \mu \mathrm{g} \mathrm{m}^{-3}\right)$ was higher than that of $\left[\mathrm{NH}_{\mathrm{x}}\right] /[\mathrm{FFOA}+\mathrm{BBOA}]\left(3.38 \mathrm{ppbv} / \mu \mathrm{g} \mathrm{m}^{-3}\right)$.

Bivariate plots of $\mathrm{NH}_{\mathrm{x}}$ (Fig. S6) show high concentration in the center area with low wind speed and also the south region with high wind speed, suggesting that the elevated $\mathrm{NH}_{\mathrm{x}}$ concentration was mainly associated with local emissions and air masses transported from the south. Regional transport could also affect primary species, e.g., BBOA and Chl. The regional characteristics of $\mathrm{NH}_{3}$ was unlikely caused by primary emissions, but rather due to the thermodynamics effect of the transported $\mathrm{NH}_{4}$. The bivariate plot of $\mathrm{f}_{\mathrm{NH} 3}$ was similar to that of $\mathrm{O}_{3}$, as both peaked when northwest wind prevailed. High $\mathrm{NH}_{3}$ was mainly associated with east wind that resulted in high $\mathrm{RH}$. The concentration of $\mathrm{NH}_{\mathrm{x}}$ was low in the northwest direction due to less emission sources of pollutants, but there was an enhancement of the concentration of $\mathrm{NH}_{3}$ in the farthest northwest direction under high wind speeds caused by the transport effect in clean situations. Sources of $\mathrm{NO}_{2}, \mathrm{SO}_{2}$, and OOA were mainly from the southwest, which was different with that of $\mathrm{NH}_{\mathrm{x}}$, indicating the weak contribution of these sources to $\mathrm{NH}_{\mathrm{x}}$. However, the distributions of the high concentrations of $\mathrm{CO}$, $\mathrm{NO}, \mathrm{BC}, \mathrm{Chl}, \mathrm{FFOA}, \mathrm{BBOA}$, and aq-OOA were generally within that of $\mathrm{NH}_{\mathrm{x}}$ in Fig. S6, indicating similar source contributions for these species. 


\subsection{Vertical profiles of $\mathrm{NH}_{3}$}

The VPs_ $b_{\text {ext }}$ in this study (Fig. S7) were classified into four categories (Table S5) as discussed in detail in Wang et al. (2018), i.e., uniformly distributed (Fig. 6a), higher at lower heights caused by enhanced local emissions (Fig. 6b), higher aloft caused by regional transport (Fig. 6c), and significant transition caused by the formation of UBL (Fig. 6d). Mostly (87\% of the time), the VPs_NH $\mathrm{NH}_{3}$ were consistent with the VPs_ $b_{\text {ext }}$. The vertical profiles of temperature in Fig. 6 followed the rules discussed in Wang et al. (2018). For example, there was no evident temperature inversion in Figs. $6 \mathrm{a}$ and $\mathrm{b}$ as the largest $T$ inversion value was $0.2^{\circ} \mathrm{C}$, but significant $T$ inversion was found in Fig. $6 \mathrm{c}\left(3.3^{\circ} \mathrm{C}\right.$ at $80 \mathrm{~m}$ to $4.8^{\circ} \mathrm{C}$ at $\left.280 \mathrm{~m}\right)$ and d $\left(3.0^{\circ} \mathrm{C}\right.$ at $80 \mathrm{~m}$ to $7.8^{\circ} \mathrm{C}$ at $\left.280 \mathrm{~m}\right)$. More detailed explanations for the four kinds of distinctive profiles can be found in Wang et al. (2018).

The $20^{\text {th }} \mathrm{VP} \_b_{\text {ext }}\left(\mathrm{VP} \_b_{\text {ext }} 20\right)$ and VP_NH $\left(\mathrm{VP} \_\mathrm{NH}_{3} \_20\right)$ (Fig. S8 and Fig. 7a) were of a new kind of vertical profile, which decreased from $130 \mathrm{~m}$ to $170 \mathrm{~m}$ and increased above $170 \mathrm{~m}$. As shown in Fig. S8, $\mathrm{PM}_{1}$ during this vertical observation was increased from $106 \mu \mathrm{g} \mathrm{m}^{-3}$ at 6:05 to $112 \mu \mathrm{g} \mathrm{m}^{-3}$ at 7:05 at ground level with SNA (= sulfate+ nitrate + ammonium) accounting for about $35 \%$ of the $\mathrm{PM}_{1}$ mass, and from $128 \mu \mathrm{g} \mathrm{m}^{-3}$ at 6:30 to $132 \mu \mathrm{g} \mathrm{m}^{-3}$ at 6:41 at $260 \mathrm{~m}$ with SNA accounting for about $43 \%$, indicating larger contribution of SNA and higher aerosol pollution level at $260 \mathrm{~m}$. Small wind $\left(\sim 2 \mathrm{~m} \mathrm{~s}^{-1}\right)$ at the height range of $260-500 \mathrm{~m}$ was from the south during 6:30 - 8:00 (Figs. S8e and $\mathrm{f}$ ), and $T$ inversion occurred at about $80 \mathrm{~m}$ (Table S5), thus the shape of VP_ $b_{\text {ext }} 20$ seemed to be a combination of the typical vertical profiles of III and IV in Figs. 6c and d, possibly caused by transport of pollutants from the south and/or the formation of low residual layer in the morning. Besides, the $\mathrm{PM}_{1}$ at $260 \mathrm{~m}$ was rich in nitrate $\left(\sim 22 \%\right.$ of $\left.\mathrm{PM}_{1}\right)$, not in ammonium $\left(\sim 10 \%\right.$ of $\left.\mathrm{PM}_{1}\right)$, 
thus, although the $b_{\text {ext }}$ was increased by $\sim 210 \mathrm{Mm}^{-1}$ from $200 \mathrm{~m}$ to $235 \mathrm{~m}$, the $\mathrm{NH}_{3}$ was just increased by $\sim 1 \mathrm{ppb}$, indicating weak particle-to-gas partitioning of $\mathrm{NH}_{\mathrm{x}}$ in case of the insufficient particle ammonium.

However, the vertical distribution of $\mathrm{NH}_{3}$ showed a more homogeneous characteristic than those of $b_{\text {ext }}$ below $260 \mathrm{~m}$ in general (Fig. S7), and occasionally, for 7\% of the time, the VPs_ $\mathrm{NH}_{3}$ varied oppositely to the VPs_ $b_{\text {ext }}$.VP_22_up ("up" means that the container was moving upward), VP_23_up (Fig. 7b) and VP_24 (Fig. 7c) were discussed here as the representative examples. The differences of RH and $T$ between VP_22_up and VP_22_down ("down" means that the container was moving downward) were less than $5 \%$ and $0.5^{\circ} \mathrm{C}$, respectively. The wind generally varied from east to south, indicating a similar meteorological condition for the two vertical profiles. $\mathrm{PM}_{1}$ at ground level and $260 \mathrm{~m}$ was increased by $28 \mu \mathrm{g} \mathrm{m}^{-3}$ and $10 \mu \mathrm{g} \mathrm{m}^{-3}$ (Fig. S9), respectively. The contributions of $\mathrm{NH}_{4}$ and $\mathrm{NO}_{3}$ were generally constant at the two heights, and the increased contribution of $\mathrm{SO}_{4}$ shall not promote the increase of $\mathrm{NH}_{3}$, thus, the difference of $\mathrm{NH}_{3}$ between VP_22_up and VP_22_down was probably due to the faster and direct emission of $\mathrm{NH}_{3}$ from fossil fuel combustion at ground level as $\mathrm{CO}, \mathrm{CO}_{2}$ and $\mathrm{NO}_{\mathrm{x}}$ in Fig. 2 all increased.

From VP_23_up to VP_23_down, $\mathrm{PM}_{1}$ decreased by $32 \mu \mathrm{g} \mathrm{m}^{-3}$ at $260 \mathrm{~m}$ while increased by 91 $\mu \mathrm{g} \mathrm{m}^{-3}$ at ground level (Fig. S9), indicating a strong accumulation of aerosol at ground level. Enhanced accumulation of $\mathrm{NO}_{\mathrm{x}}, \mathrm{SO}_{2}$, and $\mathrm{NO}_{\mathrm{z}}$ were also observed at ground level (Fig. 2). Thus, the variation of VP_NH $3 \_23 \_u p$ was mainly caused by the enhanced local $\mathrm{NH}_{3}$ emission, e. g., traffic emission and coal combustion. By contrast, the slower increase of VP_ $\mathrm{NH}_{3}$ 23_down was generally driven by the enhanced consumption of $\mathrm{NH}_{3}$ due to gas-to-particle partitioning at high level of $\mathrm{RH}(\approx$ 
$70 \%$ ) as the $\mathrm{f}_{\mathrm{NH} 3}$ was larger (Fig. 2). The UBL was confined to below $200 \mathrm{~m}$ during VP_23_down. RH was increased by $\sim 10 \%, T$ was decreased by $\sim 1^{\circ} \mathrm{C}$ below $200 \mathrm{~m}$, which would facilitate the formation of $\mathrm{NH}_{4}$, but it played a much weaker role on $\mathrm{NH}_{3}$ than on aerosol as the vertical differences of VP_NH $3 \_23 \_$down and $\mathrm{VP} \_b$ ext 23 _down were $8 \%$ and 32\%, respectively.

For VP_24, $T$ inversion occurred at about $150 \mathrm{~m}$ when $b_{\text {ext }}$ gradually decreased with the height, indicating the formation of low UBL. $\mathrm{PM}_{1}$ at $260 \mathrm{~m}$ was decreased by only $\sim 2 \%$ (from $292 \mu \mathrm{g} \mathrm{m}^{-3}$ to $286 \mu \mathrm{g} \mathrm{m}^{-3}$ ), and at ground level was by about $8 \%$ (from $433 \mu \mathrm{g} \mathrm{m}^{-3}$ to $467 \mu \mathrm{g} \mathrm{m}^{-3}$ ) (Fig. S9) from VP_24_up to VP_24_down. VP_b $b_{\text {ext_2 }} 4$ was of the type IV in Fig. 6d, but the trend of VP_NH $\mathrm{NH}_{3}$ was totally an opposite. One explanation was that, at such high level of PM and RH $(\approx 95 \%)$ below 200 $\mathrm{m}, \mathrm{NH}_{3}$ was mainly determined by gas-particle partitioning balance affected by both of the temperature and aerosol chemical composition, as to maintain an ion balance, it still needed $\mathrm{NH}_{4}(=$ $\left.\mathrm{SO}_{4} / 96 \times 2 \times 18+\mathrm{NO}_{3} / 62 \times 18+\mathrm{Chl} / 35.5 \times 18-\mathrm{NH}_{4}\right)$ of about $35 \mu \mathrm{g} \mathrm{m}^{-3}$ and $20 \mu \mathrm{g} \mathrm{m}^{-3}$, respectively at ground level and $260 \mathrm{~m}$, thus $\mathrm{NH}_{3}$ was greatly consumed to provide $\mathrm{NH}_{4}$. It is consistent with that particle is acidic during winter haze episodes (Guo et al., 2017; Liu et al., 2017). Later, higher temperature and lower aerosol mass concentration for VP_24_up caused higher values of $\mathrm{NH}_{3}$ than that for VP_24_down.

\subsection{The vertical difference between $\mathrm{NH}_{3}$ and particles}

In Fig. 8, all the data points measured during the vertically resolved experiments fell in the region defined by measurements from the ground level, indicating similar evolution mechanism of $\mathrm{NH}_{3}$ versus $b_{\text {ext }}$ below $260 \mathrm{~m}$. The data points measured during each vertically resolved experiment were usually clustered due to the uniform vertical distribution of $\mathrm{NH}_{3}$ concentration. Compared with 
the relationship between VP_NO $\mathrm{NO}_{2}$ vs VP_ $b_{\text {ext }}$ reported in Wang et al. (2018), VP_ $\mathrm{NH}_{3}$ increased faster with VP_ $b_{\text {ext }}$ and $\mathrm{NH}_{3}$ had a maximum value of about $35 \mathrm{ppb}$ in the $b_{\text {ext }}$ range of $0-2000$ $\mathrm{Mm}^{-1}$. In Fig. 9a, both $b_{\text {ext }}$ and $\mathrm{NH}_{3}$ were higher during nighttime due to lower UBL, as well as enhanced coal heating and truck emissions. The diurnal variation (= (nighttime- daytime)/whole campaign) of average VP_NH $\mathrm{NH}_{3}$ and $\mathrm{VP} \_b_{\text {ext }}$ in Fig. 9a are 0.13 and 0.93 respectively, indicating much smaller diurnal variation of VP_NH $\mathrm{NH}_{3}$ below $260 \mathrm{~m}$, which supports the result that $\mathrm{NH}_{3}$ is rich below $260 \mathrm{~m}$. The comparison between diurnal variation of average VP_NH $\mathrm{NH}_{3}$ and $\mathrm{VP} \_b_{\text {ext }}$ were shown in Fig. 9b. Regional transport and the formation of residual layer above $200 \mathrm{~m}$ caused higher values above $200 \mathrm{~m}$ during nighttime of VP_ $b_{\text {ext }}$ and VP_NH 3 . Low UBL height at nighttime resulted in the decrease in VP_b $b_{\text {ext }}$ below $200 \mathrm{~m}$, however, the VP_ $\mathrm{NH}_{3}$ showed an opposite trend mainly due to the gas-to-particle partitioning of $\mathrm{NH}_{\mathrm{x}}$. For instance, more $\mathrm{NH}_{3}$ was needed to form ammonium salt at ground level as $13 \mu \mathrm{g} \mathrm{m}^{-3}$ of $\mathrm{NH}_{4}$ was in shortage to maintain ion balance, higher than that during daytime $\left(6 \mu \mathrm{g} \mathrm{m}^{-3}\right)$ and at $260 \mathrm{~m}\left(3-8 \mu \mathrm{g} \mathrm{m}^{-3}\right)$. The nocturnal $\mathrm{NH}_{3} / b_{\text {ext }}$ was smaller than the diurnal $\mathrm{NH}_{3} / b_{\text {ext }}$, it was partly caused by large values of $\mathrm{NH}_{3} / b_{\text {ext }}$ in clean periods (Fig. S7) that usually appeared during daytime, e. g., the $\mathrm{NH}_{3} / b_{\text {ext }}$ of VPs_9 - 12, VP_15, and VP_16 were in the range of $250-1600 \mathrm{ppt} / \mathrm{Mm}^{-1}$, and the lower $T$ and higher RH (Fig. S10) during nighttime that facilitated the gas-to-particle partitioning of $\mathrm{NH}_{\mathrm{x}}$.

In Fig. S11, most VPs_ $b_{\text {ext }}$ decreased with height, however, about half of VPs_ $\mathrm{NH}_{3}$ showed opposite trend. $96 \%$ of the vertical variation (the ratios of one standard deviation to mean value (Sdev/Avg), (Max-Min)/(2×Avg)) of $\mathrm{NH}_{3}$ were smaller than that of $b_{\text {ext }}$. The average value of Sdev/Avg of VP_b $b_{\text {ext }}$ was about 4 times of that of VP_NH 3 , proving, once again, the much more homogeneous vertical distribution of $\mathrm{NH}_{3}$ in urban area in Beijing below $260 \mathrm{~m}$. 
In Fig. 10, the ratios of $\mathrm{PM}_{1}$ and $\mathrm{NH}_{4}$ at $260 \mathrm{~m}$ to ground level were 1.35 and 1.25, respectively, whereas, the ratios for $\mathrm{NH}_{3}$ and $\mathrm{f}_{\mathrm{NH} 3}$ were very close to 1 (0.98 and 0.93 , respectively; Fig. $10 \mathrm{c}$ and d). Moreover, $\mathrm{NH}_{3}$ concentration correlated better between the two heights $\left(R^{2}=0.88\right.$; Fig. 10c $)$ than $\mathrm{PM}_{1}$ or $\mathrm{NH}_{4}\left(R^{2}=0.81\right.$ for both; Fig. $10 \mathrm{a}$ and b) also suggested a more homogeneous mixing of $\mathrm{NH}_{3}$. The exponential relationships between $\mathrm{NH}_{3}$ vs. $\mathrm{PM}_{1}$ and $\mathrm{f}_{\mathrm{NH} 3}$ vs. $\mathrm{NH}_{4}$ were very similar between ground level and $260 \mathrm{~m}$ (Fig. 11), indicating similar gas-particle partitioning mechanisms below 260 $\mathrm{m}$. The small difference of DP between $8 \mathrm{~m}$ and $280 \mathrm{~m}$ (approximately $2{ }^{\circ} \mathrm{C}$ in this study; Fig. S12a) might be a reason for this similar gas-particle partitioning mechanism.

Besides, $\mathrm{SO}_{2}$ and $\mathrm{CO}$ at $260 \mathrm{~m}$ correlated well with those at ground level $\left(R^{2}=0.57\right.$ and 0.63 , respectively), indicating similar combustion sources for $\mathrm{NH}_{\mathrm{x}}$ within $260 \mathrm{~m}$ (Fig. S13a). The average ratios of $\mathrm{SO}_{2}$ and $\mathrm{CO}$ at ground level to those at $260 \mathrm{~m}$ were 0.7 and 1.1 , respectively. It is reasonable that coal combustion for residential heating has been well controlled in urban Beijing, and $\mathrm{SO}_{2}$ emitted from coal combustion was more likely from surrounding areas, especially during night time (Fig. S13b). Comparatively, CO was generally higher at ground level than $260 \mathrm{~m}$ due to the influence of traffic emissions in urban Beijing.

\section{Conclusions and implications}

The average $\mathrm{NH}_{3}$ concentration was $12.3 \mu \mathrm{g} \mathrm{m}^{-3}$ (16.5 ppb) in winter in Beijing, lower than those reported in tunnel studies and in summer in rural Beijing. $\mathrm{NH}_{3}$ remained constant during both clean periods $\left(\mathrm{PM}_{1}<17 \mu \mathrm{g} \mathrm{m}^{-3}\right)$ and heavily polluted episodes $\left(\mathrm{PM}_{1}>272 \mu \mathrm{g} \mathrm{m}^{-3}\right)$, with average concentration at about $8 \mu \mathrm{g} \mathrm{m}^{-3}$ and $17 \mu \mathrm{g} \mathrm{m}^{-3}$, respectively. Gas-particle partitioning played less distinctive role in controlling $\mathrm{NH}_{3}$ during periods with $\mathrm{PM}_{1}$ ranging from 17 to $125 \mu \mathrm{g} \mathrm{m}{ }^{-3}\left(\mathrm{NH}_{3}=8\right.$ $-16 \mu \mathrm{g} \mathrm{m}^{-3}$ ) when $\mathrm{NH}_{3}$ correlated positively and linearly with $\mathrm{PM}_{1} \cdot \mathrm{NH}_{\mathrm{x}}$ in Beijing came from 
complex sources. Primary emissions of biomass burning, coal combustion, and traffic were three significant contributors to $\mathrm{NH}_{\mathrm{x}}$. The regional transport was also a strong contribution to $\mathrm{NH}_{\mathrm{x}}$ as it correlated well with secondary species, e.g., aq-OOA, $\mathrm{NO}_{3}$, and $\mathrm{SO}_{4}$. The average wind speed was usually about $5 \mathrm{~m} \mathrm{~s}^{-1}$ at the height of $280 \mathrm{~m}$, thus the pollutants from surrounding areas within about 400 km, e.g., Hebei (Wang et al., 2014) and Shandong Provinces (Wang et al., 2016), could arrive at Beijing in one day. Once the exact sources for $\mathrm{NH}_{\mathrm{x}}$ had been resolved, the source contributions for $\mathrm{NH}_{3}$ could be reconstructed according to the good exponential relationship between $\mathrm{f}_{\mathrm{NH} 3}$ and $\mathrm{NH}_{4}$.

Vertically resolved measurements also showed four types of vertical profiles for $b_{\text {ext }}$, which were associated with well mixed atmosphere, fast accumulation of local emissions, regional transport aloft, and the formation of low urban boundary layer, consistent with those reported in Wang et al. (2018). The vertical distribution of $\mathrm{NH}_{3}$ was generally consistent with that of $b_{\text {ext }}$, but was more homogeneous due to the stronger diffusivity of $\mathrm{NH}_{3}$. The strong gas-particle partitioning effect associated with high contribution of sulfate, nitrate and chloride was an important reason for the different vertical distributions between $\mathrm{NH}_{3}$ and $b_{\text {ext }}$ during high $\mathrm{PM}$ pollution situation. The formation of UBL played a much weaker role on $\mathrm{NH}_{3}$ than on aerosol, just when both the strong temperature inversion and large aerosol gradient occurred, the formation of UBL shall play a significant role on the vertical profiles of $\mathrm{NH}_{3}$ below 260 m, e. g. VP_25 (Fig. 6d).

\section{Appendix A. Supplementary material}

Supplementary Information accompanies this paper (Figs. S1-S12, Tables S1-S5) including detailed description of the data quality, methodology, bivariate polar plots of pollution species, correlations between pollution species, aerosol chemical compositions, and information of vertical 
profiles of $\mathrm{NH}_{3}$ and $b_{\text {ext }}$.

\section{Acknowledgements}

This work was supported by the National Postdoctoral Program for Innovative Talents (BX201600157), the General Financial Grant from the China Postdoctoral Science Foundation (2017M610972), the National Natural Science Foundation of China (41705115) and the UK Natural Environment Research Council (NERC; NE/N006992/1).

\section{Notes}

The authors declare no competing financial interest.

\section{References}

Aneja, V.P., Chauhan, J.P., Walker, J.T., 2000. Characterization of atmospheric ammonia emissions from swine waste storage and treatment lagoons. J. Geophys. Res. 105, 11535-11545.

Baer, D.S., Paul, J.B., Gupta, M., O’Keefe, A., 2002. Sensitive absorption measurements in the near-infrared region using off-axis integrated-cavity-output spectroscopy. Appl. Phys. B: Lasers and Optics 75, 261-265.

Chang, Y.H., Zou, Z., Deng, C.R., Huang, K., Collett, J.L., Jr., Lin, J., Zhuang, G.S., 2015. The importance of vehicle emissions as a source of atmospheric ammonia in the megacity of Shanghai. Atmos. Chem. Phys. 15, 34719-34763.

Damme, M. V., Erisman, J. W., Clarisse, L., Dammers, E., Whitburn, S., Clerbaux, C., Dolman A. J., Coheur P. F., 2015. Worldwide spatiotemporal atmospheric ammonia $\left(\mathrm{NH}_{3}\right)$ columns variability revealed by satellite. Geophys. Res. Lett. 42, 8660-8668, doi:10.1002/2015GL065496.

Elser, M., El-Haddad, I., Maasikmets, M., Bozzetti, C., Wolf, R., Ciarelli, G., Slowik, J.G., Richter, 
R., Teinemaa, E., Hüglin, C., 2018. High contributions of vehicular emissions to ammonia in three European cities derived from mobile measurements. Atmos. Environ. 210-220.

Fu, X., Wang, S. X., Ran, L. M., Pleim, J. E., Cooter, E., Bash, J. O., Benson V., Hao J. M., 2015. Estimating $\mathrm{NH}_{3}$ emissions from agricultural fertilizer application in china using the bi-directional cmaq model coupled to an agro-ecosystem model. Atmos. Chem. Phys. 15(1), 745-778.

Giannadaki, D., Giannakis, E., Pozzer, A., Lelieveld, J., 2018. Estimating health and economic benefits of reductions in air pollution from agriculture. Sci. Total Environ. 622-623, 1304-1316.

Guo, H., Liu, J., Froyd, K.D., Roberts, J.M., Veres, P.R., Hayes, P.L., Jimenez, J.L., Nenes, A., Weber, R.J., 2017. Fine particle pH and gas-particle phase partitioning of inorganic species in Pasadena, California, during the 2010 CalNex campaign. Atmos. Chem. Phys. 17, 5703-5719.

Guo, H., Otjes, R., Schlag, P., Kiendler-Scharr, A., Nenes, A., Weber, R.J., 2018. Effectiveness of ammonia reduction on control of fine particle nitrate. Atmos. Chem. Phys. 18, 12241-12256.

Huang, Y., Lee, S.C., Ho, K.F., Ho, S.S.H., Cao, N., Cheng, Y., Gao, Y., 2012. Effect of ammonia on ozone-initiated formation of indoor secondary products with emissions from cleaning products. Atmos. Environ. 59, 224-231.

Li, Q., Jiang, J., Cai, S., Zhou, W., Wang, S., Duan, L., Hao, J., 2016. Gaseous Ammonia Emissions from Coal and Biomass Combustion in Household Stoves with Different Combustion Efficiencies. Environ. Sci. Technol. Lett. 3, 98-103.

Li, Y., Schwab, J.J., Demerjian, K.L., 2006. Measurements of ambient ammonia using a tunable diode laser absorption spectrometer: Characteristics of ambient ammonia emissions in an urban area of New York City. J. Geophys. Res. 111, 1599-1609. 
Liu, M., Song, Y., Zhou, T., Xu, Z., Yan, C., Zheng, M., Wu, Z., Hu, M., Wu, Y., Zhu, T., 2017. Fine particle pH during severe haze episodes in northern China. Geophys. Res. Lett. 44, 5213-5221.

Liu, T., Wang, X., Wang, B., Ding, X., Deng, W., Lü, S., Zhang, Y., 2014. Emission factor of ammonia (NH3) from on-road vehicles in China: tunnel tests in urban Guangzhou. Environ. Res. Lett. 9, 064027.

Liu, X., Cheng, X., Hu, F., 2015. Gradient characteristics of CO2 concentration and flux in Beijing urban area part I: Concentration and virtual temperature. Chinese J. Geophys. (in Chinese) 58, $1502-1512$.

Meng, Z., Xu, X., Lin, W., Ge, B., Xie, Y., Song, B., Jia, S., Zhang, R., Peng, W., Wang, Y., Cheng, H., Yang, W., Zhao, H., 2018. Role of ambient ammonia in particulate ammonium formation at a rural site in the North China Plain. Atmos. Chem. Phys. 18, 167-184.

Millet, D.B., Baasandorj, M., Hu, L., Mitroo, D., Turner, J., Williams, B.J., 2016. Nighttime Chemistry and Morning Isoprene Can Drive Urban Ozone Downwind of a Major Deciduous Forest. Environ. Sci. Technol. 50, 4335-4342.

Na, K., Song, C., Iii, D.R.C., 2006. Formation of secondary organic aerosol from the reaction of styrene with ozone in the presence and absence of ammonia and water. Atmos. Environ. 40, 1889-1900.

Nowak, J.B., Neuman, J.A., Bahreini, R., Middlebrook, A.M., Holloway, J.S., Mckeen, S.A., Parrish, D.D., Ryerson, T.B., Trainer, M., 2012. Ammonia sources in the California South Coast Air Basin and their impact on ammonium nitrate formation. Geophys. Res. Lett. 39, 102-114.

Pan, Y., Tian, S., Liu, D., Fang, Y., Zhu, X., Gao, M., Gao, J., Michalski, G., Wang, Y., 2018. Isotopic evidence for enhanced fossil fuel sources of aerosol ammonium in the urban atmosphere. 
Environ. Pollut. 238, 942-947.

Pan, Y., Tian, S., Liu, D., Fang, Y., Zhu, X., Zhang, Q., Zheng, B., Michalski, G., Wang, Y., 2016. Fossil Fuel Combustion-Related Emissions Dominate Atmospheric Ammonia Sources during Severe Haze Episodes: Evidence from 15N-Stable Isotope in Size-Resolved Aerosol Ammonium. Environ. Sci. Technol. 50, 8049-8056.

Pozzer, A., Tsimpidi, A.P., Karydis, V.A., de Meij, A., Lelieveld, J., 2017. Impact of agricultural emission reductions on fine-particulate matter and public health. Atmos. Chem. Phys. 17, 12813-12826.

Shen, J., Liu, X., Zhang, Y., Fangmeier, A., Goulding, K., Zhang, F., 2011. Atmospheric ammonia and particulate ammonium from agricultural sources in the North China Plain. Atmos. Environ. $45,5033-5041$.

Sun, K., Tao, L., Miller, D.J., Khan, M.A., Zondlo, M.A., 2014a. On-Road Ammonia Emissions Characterized by Mobile, Open-Path Measurements. Environ. Sci. Technol. 48, 3943.

Sun, Y., Jiang, Q., Wang, Z., Fu, P., Li, J., Yang, T., Yin, Y., 2014b. Investigation of the sources and evolution processes of severe haze pollution in Beijing in January 2013. J. Geophys. Res. 119, 4380-4398.

Sun, Y., Wang, Z., Dong, H., Yang, T., Li, J., Pan, X., Chen, P., Jayne, J.T., 2012. Characterization of summer organic and inorganic aerosols in Beijing, China with an Aerosol Chemical Speciation Monitor. Atmos. Environ. 51, 250-259.

Sun, Y., Wang, Z., Fu, P., Yang, T., Jiang, Q., Dong, H., Li, J., Jia, J., 2013. Aerosol composition, sources and processes during wintertime in Beijing, China. Atmos. Chem. Phys. 13, 4577-4592.

Sun, Y., Wei, D., Wang, Q., Zhang, Q., Chen, C., Chen, Y., Chen, Z., Fu, P., Wang, Z., Gao, Z., 2015. 
Real-Time Characterization of Aerosol Particle Composition above the Urban Canopy in Beijing: Insights into the Interactions between the Atmospheric Boundary Layer and Aerosol Chemistry. Environ. Sci. Technol. 49, 11340-11347.

Teng, X., Hu, Q., Zhang, L., Qi, J., Shi, J., Xie, H., Gao, H., Yao, X., 2017. Identification of Major Sources of Atmospheric NH3 in an Urban Environment in Northern China During Wintertime. Environ. Sci. Technol. 51, 6839.

Tevlin, A.G., Li, Y., Collett, J.L., McDuffie, E.E., Fischer, E.V., Murphy, J.G., 2017. Tall Tower Vertical Profiles and Diurnal Trends of Ammonia in the Colorado Front Range. J. Geophys. Res. $122,12468-12487$.

Van Damme, M., Clarisse, L., Whitburn, S., Hadji-Lazaro, J., Hurtmans, D., Clerbaux, C., Coheur, P.-F., 2018. Industrial and agricultural ammonia point sources exposed. Nature 564, 99-103.

Wang, L., Wei, Z., Yang, J., Zhang, Y., Zhang, F., Su, J., Meng, C., Zhang, Q., 2014. The 2013 severe haze over the southern Hebei, China: model evaluation, source apportionment, and policy implications. Atmos. Chem. Phys. 14, 3151-3173.

Wang, Q., Sun, Y., Jiang, Q., Du, W., Sun, C., Fu, P., Wang, Z., 2015. Chemical composition of aerosol particles and light extinction apportionment before and during heating season in Beijing, China. J. Geophys. Res. 120, 12708-12722.

Wang, Q., Sun, Y., Xu, W., Du, W., Zhou, L., Tang, G., Chen, C., Cheng, X., Zhao, X., Ji, D., Han, T., Wang, Z., Li, J., Wang, Z., 2018. Vertically resolved characteristics of air pollution during two severe winter haze episodes in urban Beijing, China. Atmos. Chem. Phys. 18, 2495-2509.

Wang, S., Xing, J., Jang, C., Zhu, Y., Fu, J.S., Hao, J., 2011. Impact Assessment of Ammonia Emissions on Inorganic Aerosols in East China Using Response Surface Modeling Technique. 
Environ. Sci. Technol. 45, 9293-9300.

Wang, Y., Bao, S., Wang, S., Hu, Y., Shi, X., Wang, J., Zhao, B., Jiang, J., Zheng, M., Wu, M., 2016. Local and regional contributions to fine particulate matter in Beijing during heavy haze episodes. Sci. Total Environ. 580, 283-296.

Xu, W., Sun, Y., Wang, Q., Zhao, J., Wang, J., Ge, X., Xie, C., Zhou, W., Du, W., Li, J., Fu, P., Wang, Z., Worsnop, D.R., Coe, H., 2018. Changes in Aerosol Chemistry from 2014 to 2016 in Winter in Beijing: Insights from High Resolution Aerosol Mass Spectrometry. J. Geophys. Res. 124, $1132-1147$.

Zhang, J.K., Wang, Y.S., Huang, X.J., Liu, Z.R., Ji, D.S., Sun, Y., 2015. Characterization of organic aerosols in Beijing using an aerodyne high-resolution aerosol mass spectrometer. Adv. Atmos. Sci. 32, 877-888.

Zhang, X., Wu, Y., Liu, X., Reis, S., Jin, J., Dragosits, U., Van, D.M., Clarisse, L., Whitburn, S., Coheur, P.F., 2017. Ammonia emissions may be substantially underestimated in China. Environ. Sci. Technol. 51, 12089-12096.

Zhang, Y., Tang, A., Wang, D., Wang, Q., Benedict, K., Zhang, L., Liu, D., Li, Y., Collett Jr, J.L., Sun, Y., Liu, X., 2018. The vertical variability of ammonia in urban Beijing, China. Atmos. Chem. Phys. 18, 16385-16398. 


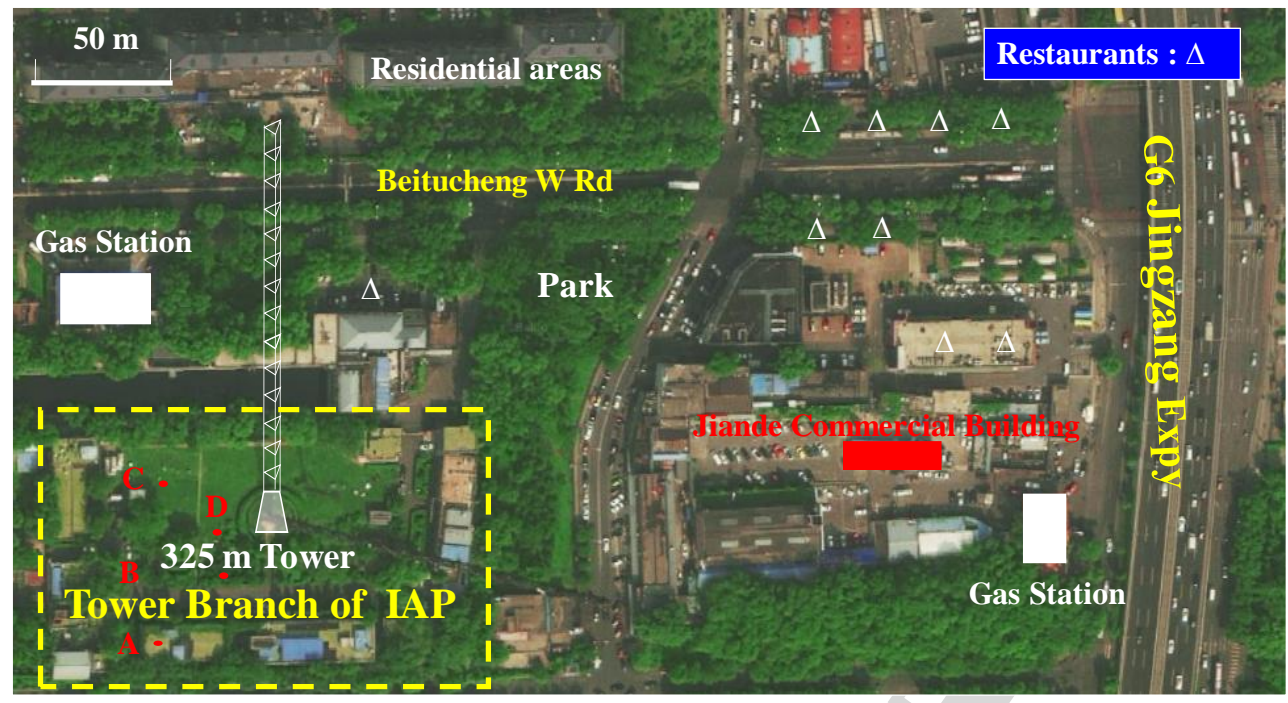

Fig. 1. Sampling site and its surroundings.
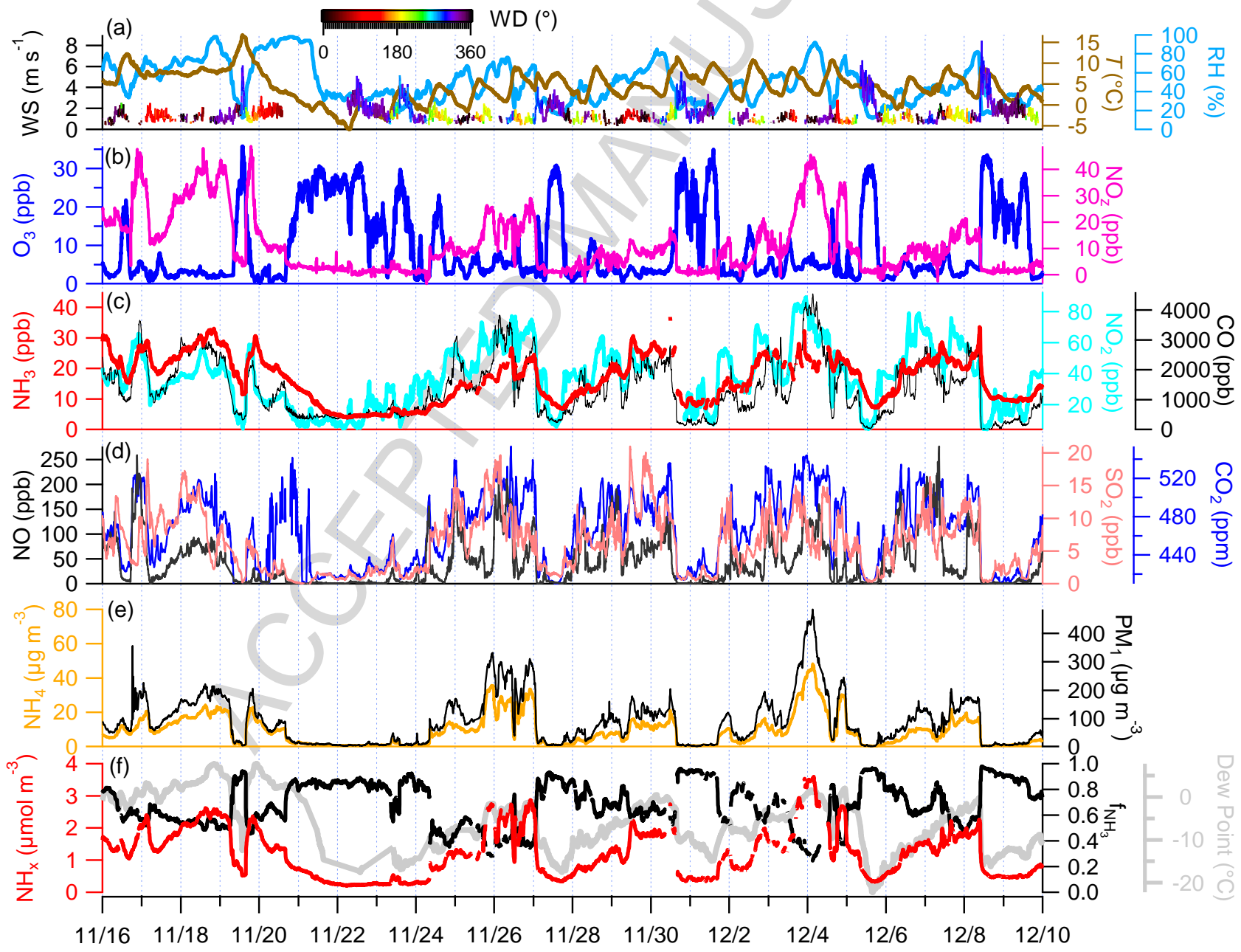

Fig. 2. Time series of (a) WS, WD, RH, and T; (b) $\mathrm{O}_{3}$ and $\mathrm{NO}_{\mathrm{z}}$; (c) $\mathrm{NH}_{3}, \mathrm{NO}_{2}$, and $\mathrm{CO}$; (d) $\mathrm{NO}$, 
$\mathrm{SO}_{2}$, and $\mathrm{CO}_{2}$; mass concentrations of (e) $\mathrm{NH}_{4}$ and $\mathrm{PM}_{1}$; (f) molar concentration of $\mathrm{NH}_{\mathrm{x}}$, $\mathrm{f}_{\mathrm{NH} 3}$, and dew point at the ground level of $\operatorname{TBIAP}\left(39^{\circ} 58^{\prime} \mathrm{N}, 116^{\circ} 22^{\prime} \mathrm{E}\right.$; elevation: $\left.49 \mathrm{~m} \mathrm{ASL}\right)$.
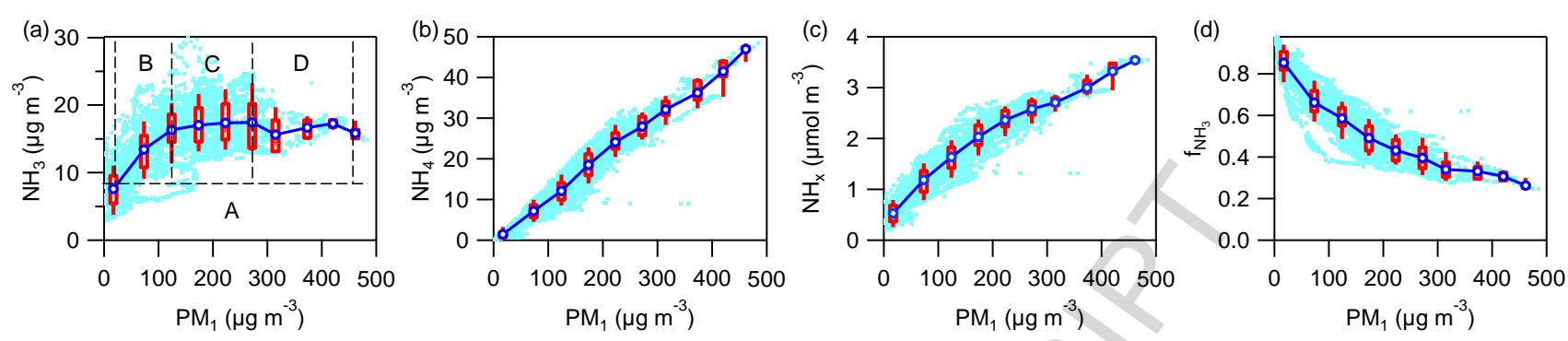

Fig. 3. Variations of (a) $\mathrm{NH}_{3}$, (b) $\mathrm{NH}_{4}$, (c) $\mathrm{NH}_{\mathrm{x}}$, and (d) $\mathrm{f}_{\mathrm{NH} 3}$ as a function of $\mathrm{PM}_{1}$ mass concentration with the boxes showing the mean (blue circles), median, 10th, 25th, 75th and 90th percentiles of the data values.

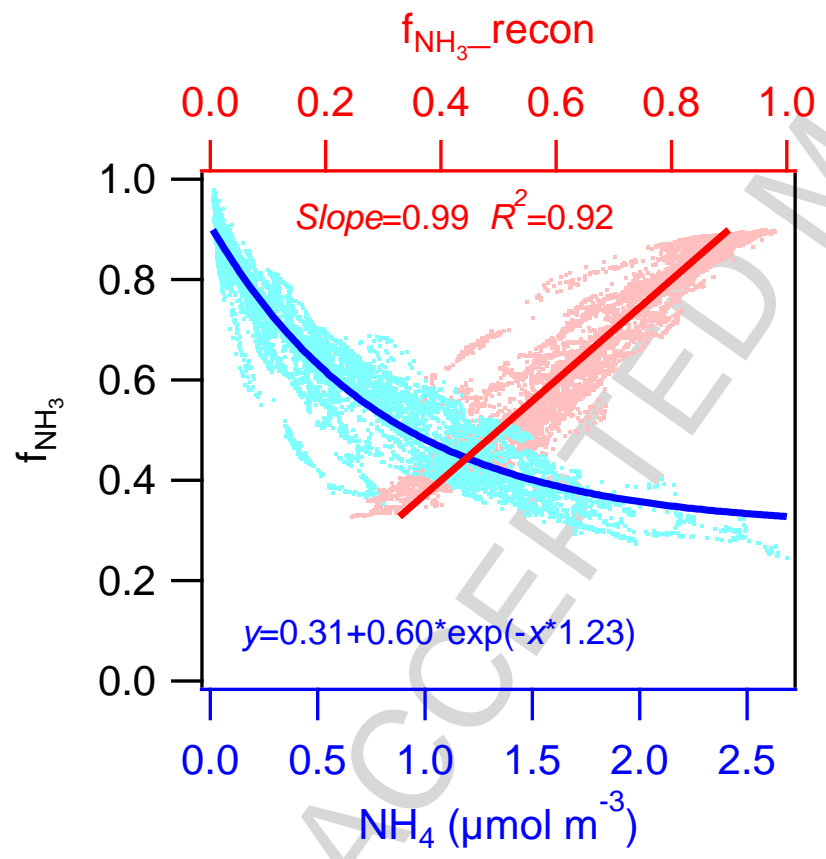

Fig. 4. Relationships between $\mathrm{f}_{\mathrm{NH} 3}$ and $\mathrm{NH}_{4}$, and between measured and reconstructed $\mathrm{f}_{\mathrm{NH} 3}$ with $\mathrm{NH}_{4}$. 

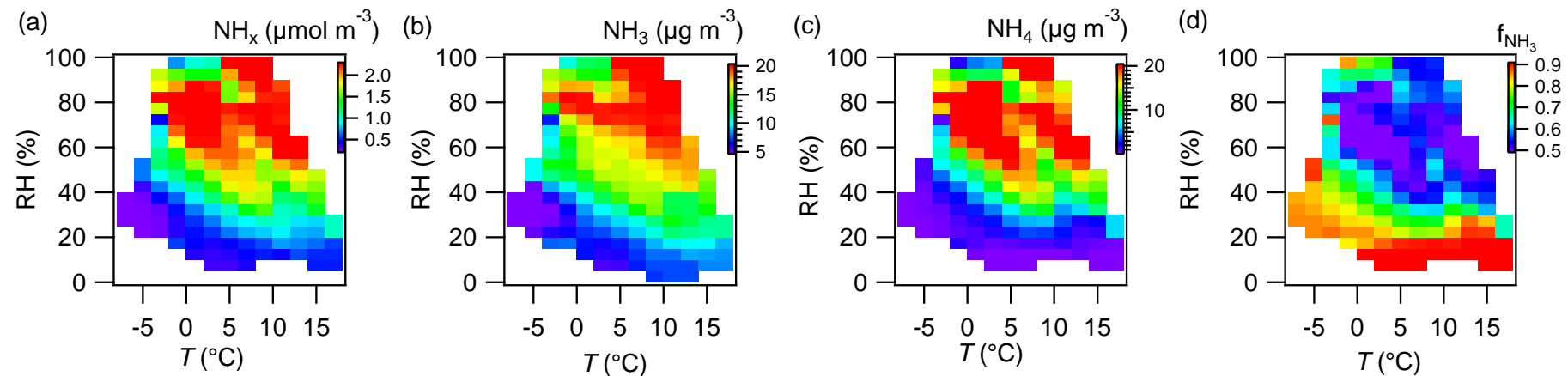

Fig. 5. RH and $T$ dependence of (a) molar concentration of $\mathrm{NH}_{\mathbf{x}}$, mass concentration of (b) $\mathrm{NH}_{3}$ and (c) $\mathrm{NH}_{4}$, and (d) $\mathbf{f}_{\mathrm{NH} 3}$.
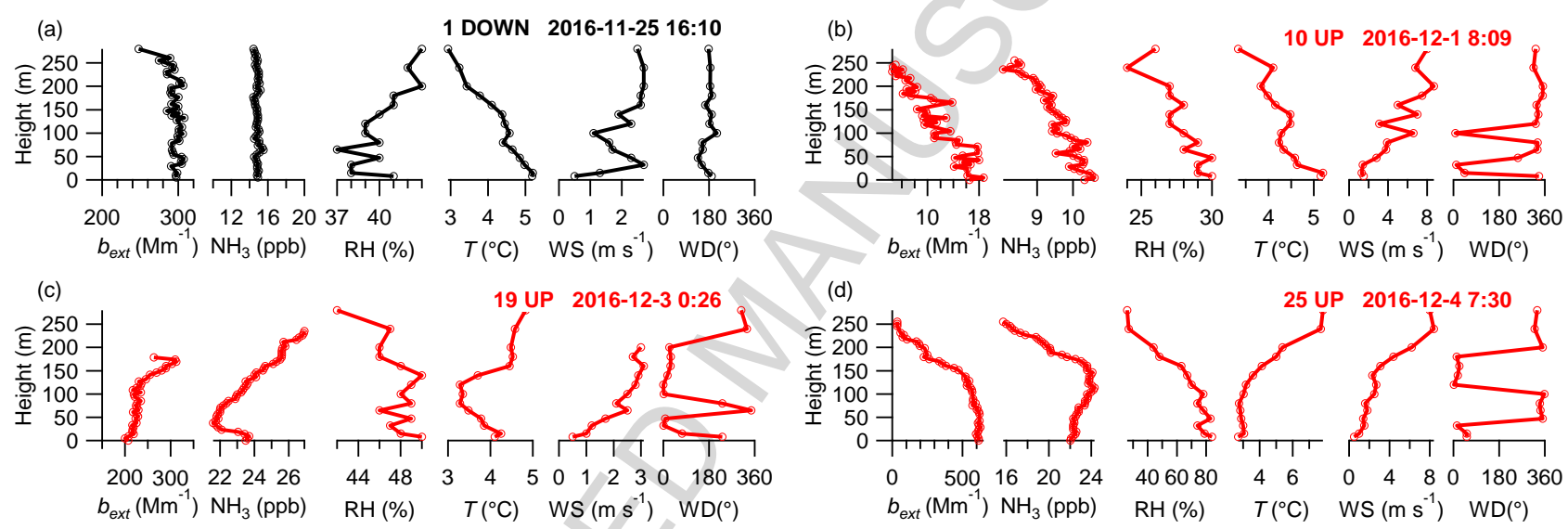

Fig. 6. Examples for four typical types of $\mathrm{VP}_{-} \mathrm{NH}_{3}$ which are consistent with of VP_b $b_{\text {ext }}$ according to the results reported in Wang et al. (2018), together with the corresponding vertical profiles of RH, WD, WS, and $T$. The serial number of the vertically resolved experiments were added in each figure, and the moving directions of the container were marked in red (UP) and black (DOWN) color, respectively. 

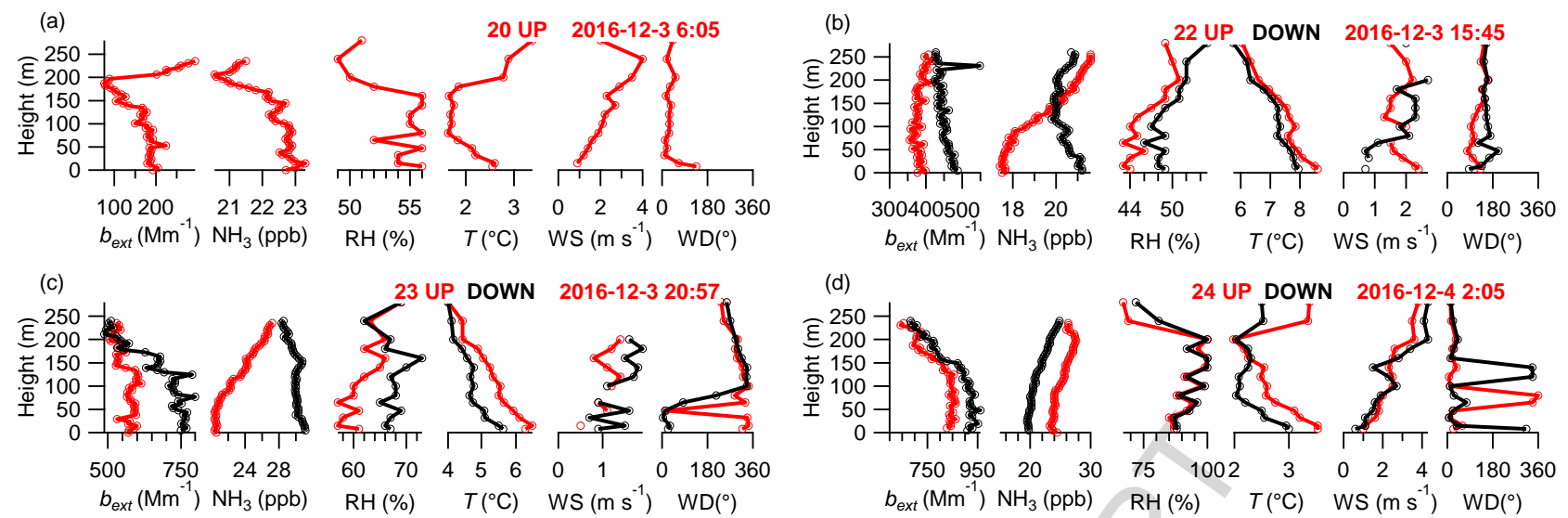

Fig. 7. The typical types of $\mathrm{VP}_{-} \mathrm{NH}_{3}$ that could not be classified with the method in Wang et al. (2018), together with the corresponding vertical profiles of $b_{\text {ext }}, \mathrm{RH}$, and $T$. The serial number of the vertically resolved experiments were added in each figure, and the moving directions of the container were marked in red (UP) and black (DOWN) color for the vertical profiles, respectively.

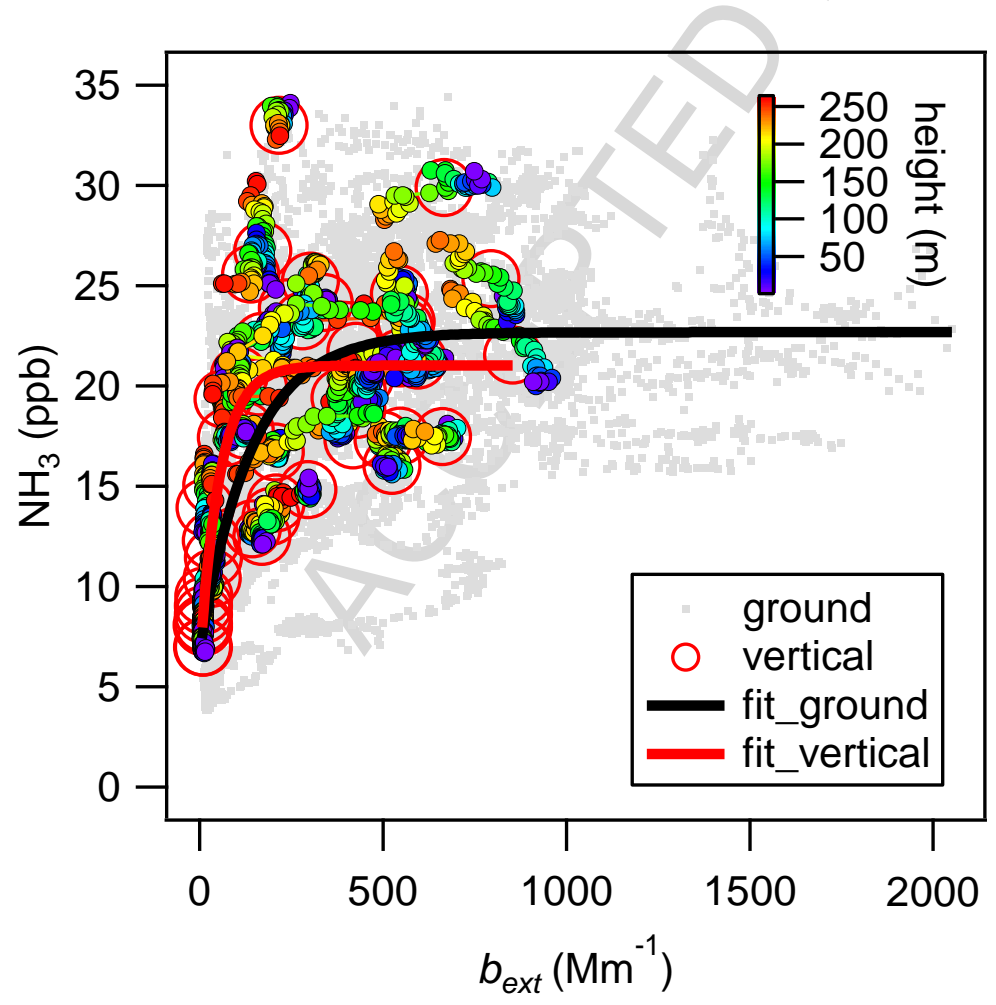

Fig. 8. Comparison of $\mathrm{NH}_{3}$ vs $b_{\text {ext }}$ measured at ground level (gray points) and during vertically 
resolved measurements (round points colored by heights were measured during each vertically resolved measurement, red circles are the average values for each vertically resolved measurement.
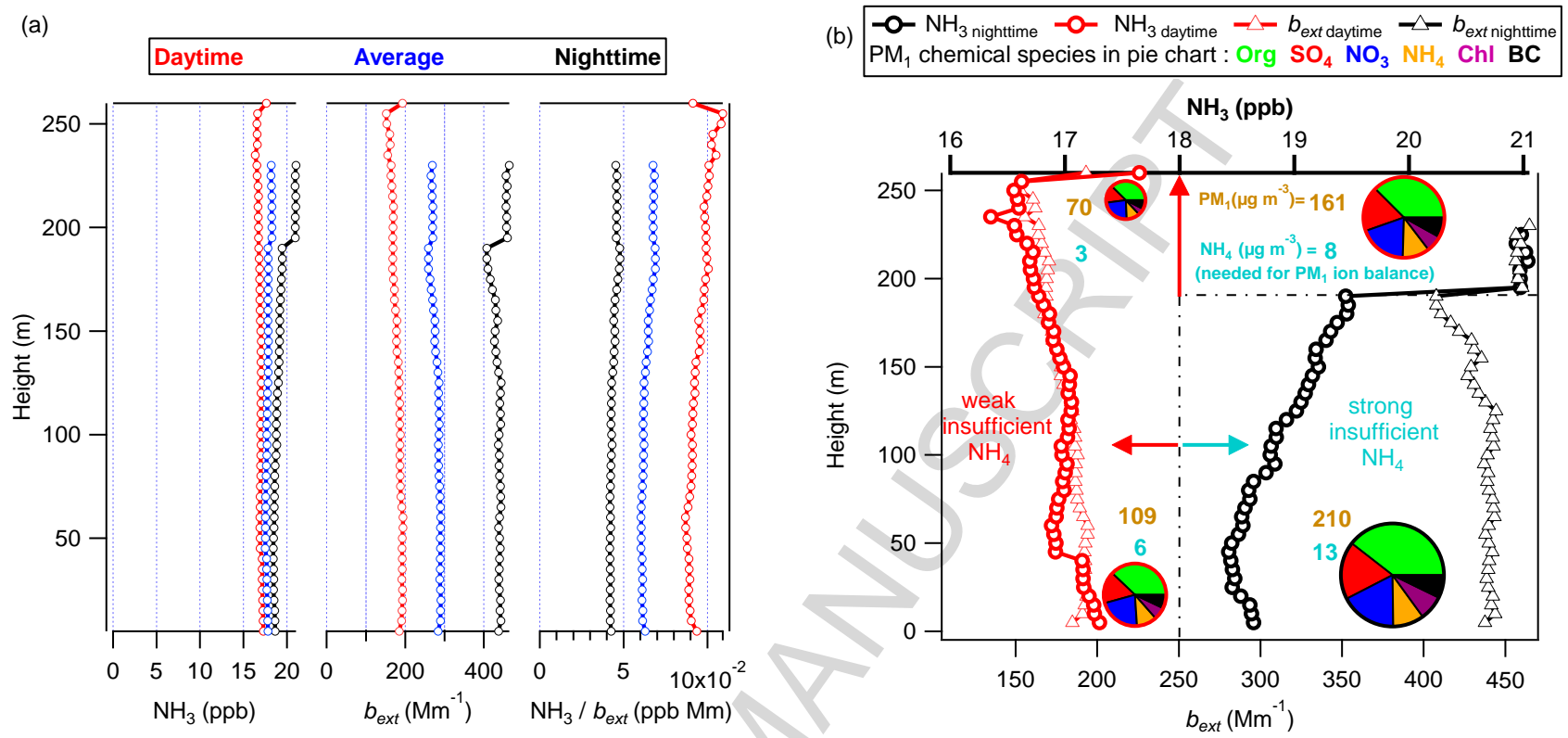

Fig. 9. Average vertical distribution of (a) $b_{\text {ext }}, \mathrm{NH}_{3}$, and $\mathrm{NH}_{3} / b_{\text {ext }}$ for all data points, and for data points that during daytime and nighttime, respectively. (b) Comparison of vertical distribution of $\mathrm{NH}_{3}$ vs $b_{\text {ext }}$ measured during daytime and nighttime and the corresponding PM chemical composition at $260 \mathrm{~m}$ and ground level.
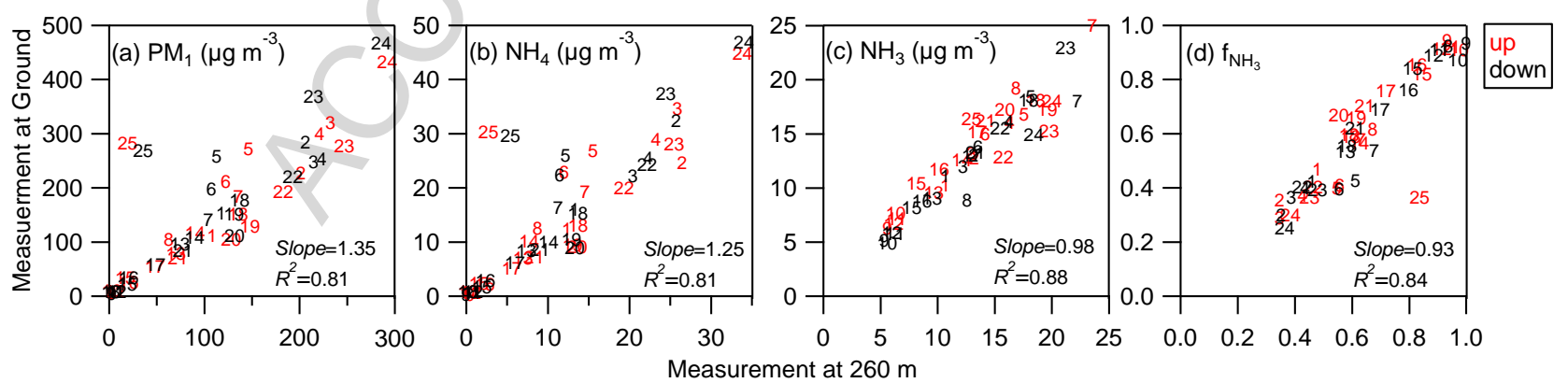

Fig. 10. Comparisons of (a) $\mathrm{PM}_{1}$, (b) $\mathrm{NH}_{4}$, (c) $\mathrm{NH}_{3}$ and (d) $\mathrm{f}_{\mathrm{NH} 3}$ between $260 \mathrm{~m}$ and ground level. Data points were marked by the serial number of the experiments (Fig. S7). Data points 
measured for up and down experiments were marked in red and black color, respectively. Data points for down experiment 14, 19, 20, and 25 were not used for calculation of $\boldsymbol{R}^{2}$ and Slope due to the incomplete measurement of $\mathrm{VP}_{-} \mathrm{NH}_{3} . \mathrm{NH}_{3}$ measured at $240 \mathrm{~m}$ during nighttime was approximately used as the value at $260 \mathrm{~m}$ as the moving time from $240 \mathrm{~m}$ to $260 \mathrm{~m}$ is about 2.5 minutes (=20/8min).

(a)

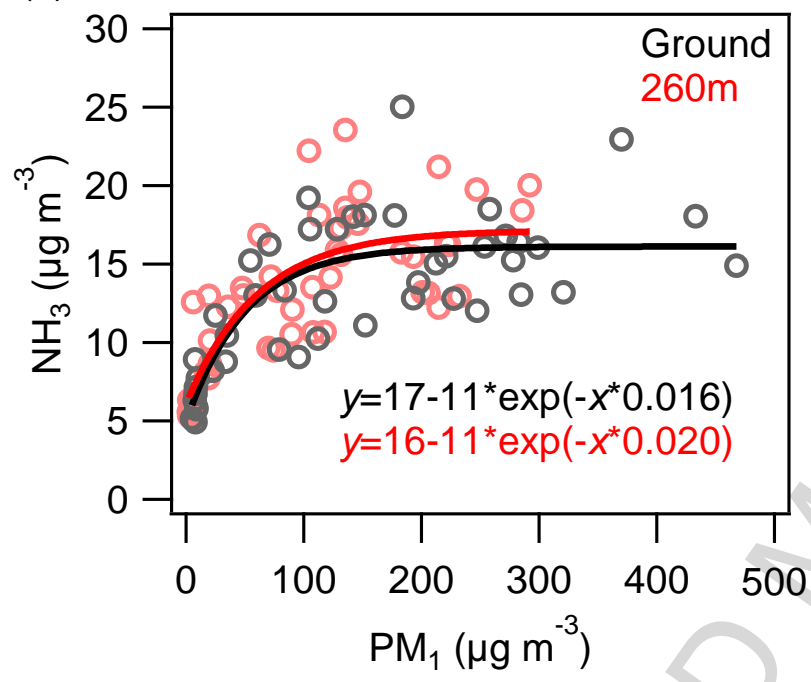

(b)

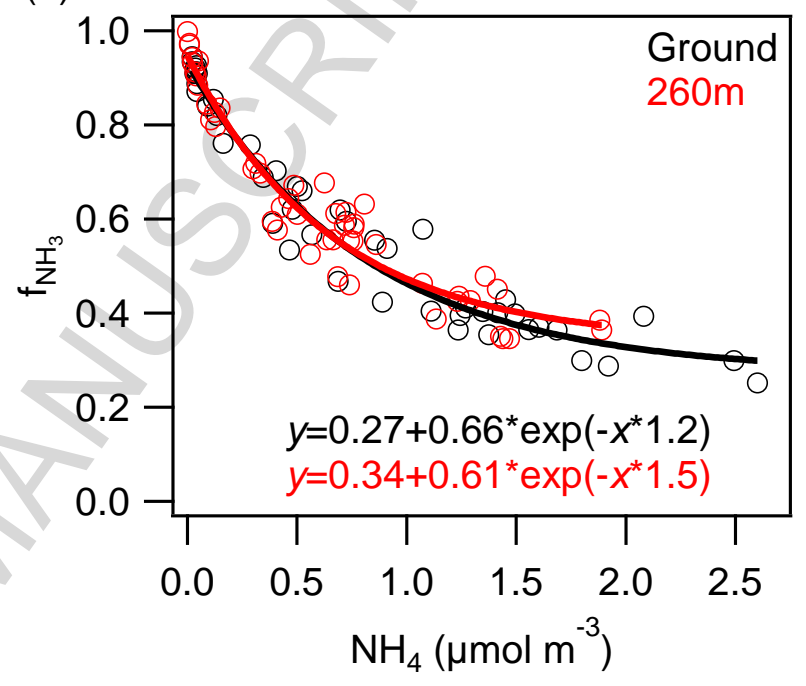

Fig. 11. (a) Variations of $\mathrm{NH}_{3}$ as a function of $\mathrm{PM}_{1}$ mass concentration, and (b) relationship between $\mathrm{f}_{\mathrm{NH} 3}$ and $\mathrm{NH}_{4}$ concentration at ground level (black circles) and $260 \mathrm{~m}$ (red circles) during the vertically resolved experiments. 


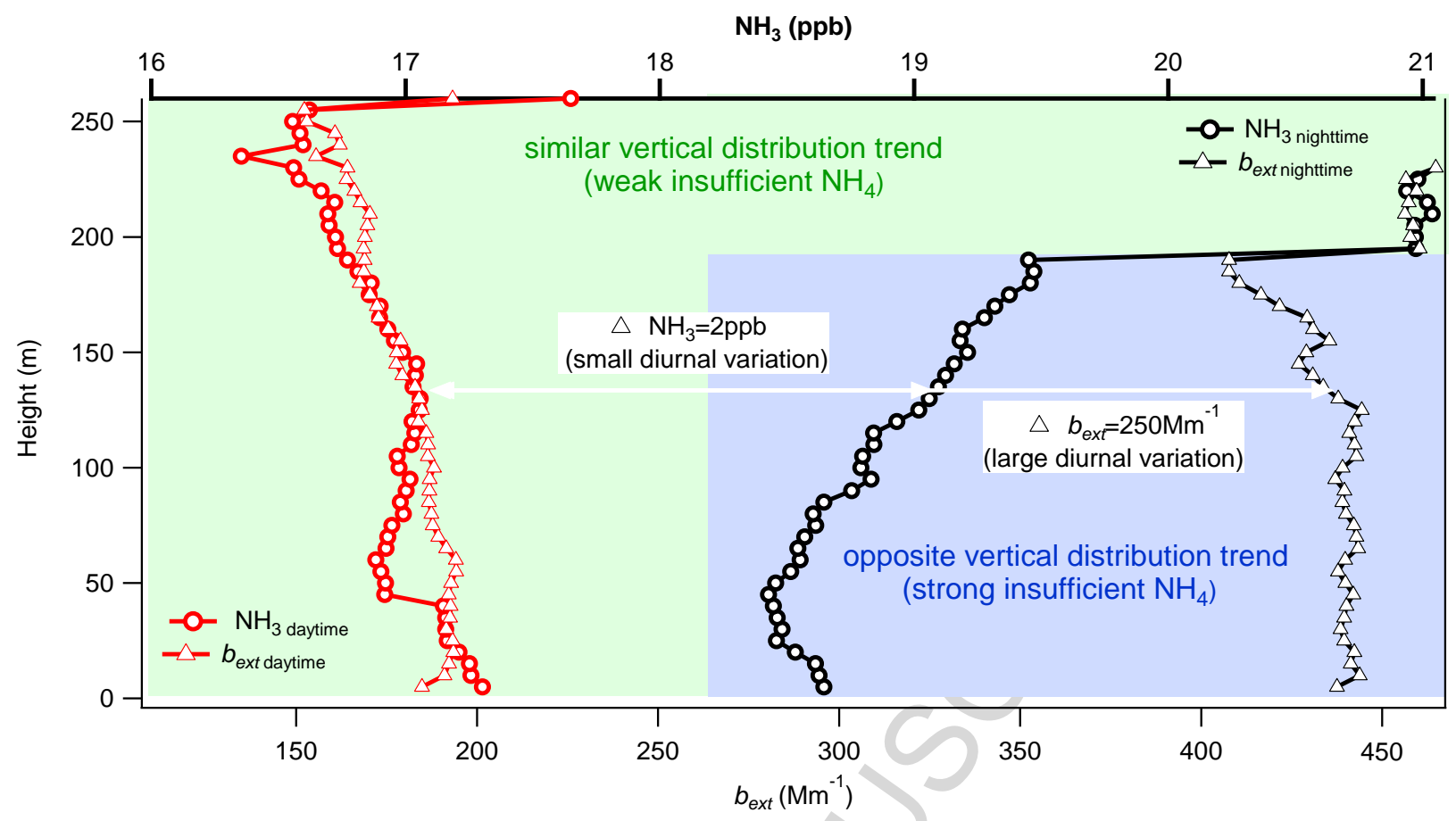

Graphical abstract 


\section{HIGHLIGHTS}

Gas-particle partitioning plays a significant role on $\mathrm{NH}_{3}$ concentration.

$\mathrm{NH}_{3}$ remains relatively constant at high $\mathrm{PM}$ and $\mathrm{NH}_{4}$ levels.

Gas-to-particle partitioning can cause opposite vertical profiles of $\mathrm{NH}_{3}$ and $b_{\text {ext }}$.

Vertical distribution of $\mathrm{NH}_{3}$ is more homogeneous than that of $b_{\text {ext }}$ 